CIRJE-F-848

\title{
Should the Japanese Tax System Be More Progressive? An Evaluation Using the Simulated SMCFs Based on the Discrete Choice Model of Labor Supply
}

\author{
Shun-ichiro Bessho \\ Keio University
}

Masayoshi Hayashi

The University of Tokyo

April 2012, Revised in January 2014

CIRJE Discussion Papers can be downloaded without charge from:

http://www.cirje.e.u-tokyo.ac.jp/research/03research02dp.html

Discussion Papers are a series of manuscripts in their draft form. They are not intended for circulation or distribution except as indicated by the author. For that reason Discussion Papers may not be reproduced or distributed without the written consent of the author. 


\title{
Should the Japanese Tax System Be More Progressive? An Evaluation Using the Simulated SMCFs Based on the Discrete Choice Model of Labor Supply
}

\author{
Shun-ichiro Bessho ${ }^{a}$ \\ Masayoshi Hayashi ${ }^{b}$
}

\begin{abstract}
This study proposes a method to obtain the social marginal costs of public funds (SMCF) that allows for heterogeneity on a household basis as well as labor supply responses along both the extensive and the intensive margins. To demonstrate our methodology, we take the example of the 1999 national income tax reform in Japan and evaluate it by estimating the SMCFs for changing marginal tax rates in different income brackets. We estimate the discrete choice model (DCM) of labor supply using a 1997 data set of Japanese households, and we use the estimates to generate the SMCFs with a DCM micro-simulation. We evaluate the simulated SMCFs with various distributional weights and find that the value of the SMCF for a $1 \%$ increase in the marginal tax rate in any given income bracket decreases as we move across brackets from the bottom to the top. This finding suggests that the national government should have made the Japanese income tax system more progressive rather than less progressive as carried out in the 1999 reform. Our method is readily transferrable to tax reforms in other countries as well.
\end{abstract}

JEL Codes: H21, H24, H31, J22

Keywords: Social marginal cost of public funds; discrete choice model; household labor supply; Japan

\footnotetext{
${ }^{a}$ Faculty of Economics, Keio University, 2-15-45 Mita, Minato-ku, Tokyo 108-8345, Japan. E-mail: bessho@econ.keio.ac.jp. Tel: +81-3-5427-1360.

${ }^{\mathrm{b}}$ Faculty of Economics, The University of Tokyo, 7-3-1, Hongo, Bunkyo-ku, Tokyo 113-0033, Japan.

E-mail: hayashim@e.u-tokyo.ac.jp.
} 


\section{Introduction}

Many industrial countries have flattened their income tax systems over the decades. Japan is not an exception. While its national personal income tax system had 15 income brackets and imposed $70 \%$ tax as the top marginal tax rate in the 1980s, the tax reform in 1991 reduced the number of brackets to five and the top marginal tax rate to $50 \%$. Another reform in 1999 flattened the system further by reducing the brackets to four and the top rate to $37 \%$. Indeed, literature on optimal taxation contributed to the flattening of the tax system, emphasizing the importance of "incentives to work" via tax reduction and the significance of "welfare distortion" brought about by progressive taxes (Bessho and Hayashi 2005, 2011; Hayashi 2009). Thus, the flattening of the tax system in the 1999 reform must have aimed to improve welfare. However, no studies have attempted to evaluate empirically if the reform was actually desirable. Our first objective is to fill this gap in the literature by examining whether the 1999 tax reform in Japan was welfare improving.

One of the measures to evaluate the optimality of a tax system is the marginal cost of public funds (MCF) (Dahlby 2008). The set of MCFs over different tax instruments indicates a desirable direction of tax changes, as an optimal set of tax rates requires their MCFs to be identical. However, since progressive income taxation presumes heterogeneous households, the MCF does not provide an ideal fit for our analysis, as they presume a homogeneous single-agent economy. The analogue to the MCF in a heterogeneous economy is the social marginal cost of public funds (SMCF) (Dahlby 1998, Sandmo 1998, Liu 2006, Bessho and Hayashi 2013). In particular, Dahlby (1998) formulated the concept of the SMCF and applied it to evaluate a progressive system of personal income taxes by estimating the SMCFs for each income bracket. The values of the SMCFs across different income brackets indicate the desirable direction the system should follow: an optimal system requires the SMCFs to 
be equalized across the brackets. ${ }^{1}$ In this study, we evaluate the 1999 national income tax reform in Japan by comparing the SMCFs for changing marginal tax rates in different income brackets.

However, this study is more than a simple application of SMCF analysis. In particular, we propose a method to calculate the SMCF that addresses the following three issues in the SMCF literature. The first issue concerns individual heterogeneity of labor supply along the extensive margin. To date, the literature has not proposed an SMCF that allows for individually heterogeneous labor supply response along the extensive margin, in addition to the one along the intensive margin. In their study on the SMCF, while Kleven and Kreiner (2006) considered both the intensive and the extensive margins, they modeled consumer heterogeneity by assuming different groups of identical households. While Bessho and Hayashi (2013) differentiated labor supply on an individual basis in their estimation of the SMCF, they restricted their analysis to the responses along the intensive - and not extensive - margin. The empirical studies do not help either. They typically estimate the two types of labor responses separately, one as a probability of labor market participation and the other as a continuous choice of labor supply after the participation (Kimmel and Kniesner 1998). Estimating the SMCF from these two estimates is not straightforward. We address this issue by taking advantage of the discrete choice model (DCM) of labor supply, as it estimates labor supply responses along both the extensive and the intensive margins in a single estimation.

The second issue originates in the DCM estimation itself. Following Van Soest (1995), an increasing number of studies utilized the DCM to analyze the effects of taxes and transfers on labor supply, because its estimation is robust to the existence of

\footnotetext{
${ }^{1}$ This is a tax reform exercise, not a tax design exercise. A tax reform analysis is more practical than a tax design analysis, as it evaluates piecemeal changes from the existing system. On the other hand, tax design calls for an entirely new system by quantifying the optimal value for every tax rate (cf., Feldstein 1976).
} 
non-convex budget sets typically caused by the systems of taxes and transfers (Blundell and MaCurdy 1999, Bargain et al. 2011). Despite such popularity, however, the literature has not applied the DCM to estimate either the SMCF or the MCF. This is understandable since, by construction, the DCM presumes discrete choices of labor supply. When we estimate labor supply responses with the DCM, we cannot simply apply the standard SMCF formula that utilizes the compensated elasticity of and the income effect on continuous labor supply (Dahlby 1998). In this study, we contribute to the literature by demonstrating how to apply the DCM to the SMCF estimation. Our proposed method calibrates discrete labor supply choices of individual households and simulates an analogue of the SMCF.

The third issue concerns the aggregation of individual welfare (utility), which is very much inherent in the definition of the SMCF. Our sample consists of singles and couples with or without children, each of whom has a different specification of the utility function with different values of structural parameters. It may thus be inappropriate to treat all their "raw" utility levels as comparable. To accommodate this difficulty, the empirical literature has proposed two aggregation methods. The first type artificially sets up an analogue of utility function, or a score function, that treats all types of households as if they were identical, and it aggregates the scores over all the households through a standard social welfare function (Ericson and Flood 2009, Aaberge and Colombino 2013). Apparently, this sort of social evaluation imposes artificial preferences on households and therefore, does not respect their individual preferences or the Pareto principle (Decoster and Haan 2010, Creedy et al. 2011). Given this criticism, the second type of aggregation proposes a new metric that does not violate the Pareto principle. In particular, Decoster and Haan (2010) elaborated on such metrics by Fleurbaey (2006) and applied them to labor consumption choice. More importantly, Fleurbaey et al. (2013) operationalized one of the three metrics, which 
Fleurbaey (2008) called the "equivalent approach," to construct the distributional weights. We utilize this approach along with alternatives that are apparently ad hoc but seemingly popular. This study is thus one of the few studies that utilize Fleurbaey's distributional weights and possibly the first one that applies the concept to the SMCF.

The remainder of this paper proceeds as follows. Section 2 explicates the standard DCM estimation and our procedure to simulate the SMCF. Section 3 specifies household preferences, delineates the Japanese income tax system, and describes the sample and the variables used for the estimation. This section also estimates preference parameters and uses them to obtain the choice probabilities of households to quantify labor supply responses. Section 4 simulates the SMCFs for a small increase in the marginal tax rate in each of the five income brackets of the national personal income tax and discusses the results. Section 5 concludes this study.

\section{Simulating the SMCF}

\subsection{The DCM Estimation of Preference Parameters}

We first describe how to estimate preference parameters using the DCM of labor supply. We will utilize these parameters to simulate the SMCFs. We start with a single-member household $i$ that faces $J$ discrete levels of labor supply $\left\{h_{i 1}, h_{i 2}, \ldots, h_{i J}\right\}$. Its utility level is

$$
U_{i j}=U\left(c_{i}, l_{i j} \mid Z_{i}\right)+e_{i j}
$$

where $U(\cdot)$ is increasing in consumption $c_{i}$ and leisure $l_{i j} \equiv T-h_{i j}(T$ is time endowment), and unobservable error $e_{i j} \equiv e\left(h_{i j}\right)$ is choice-specific. Since tax liability $R_{i}=R\left(W_{i} h_{i j}, Z_{i}\right.$, $\tau)$ depends on labor income $W_{i} h_{i j}\left(W_{i}\right.$ is the gross wage rate), household characteristics $\boldsymbol{Z}_{i}$, and tax parameter $\tau$, we can express the consumption level as

$$
c_{i}=W_{i} h_{i j}-R\left(W_{i} h_{i j}, Z_{i}, \tau\right) \text {. }
$$


We then see that the choice of $h_{i j}$ determines the utility level

$$
U_{i j} \equiv V\left(h_{i j}, Z_{i}, \boldsymbol{\tau}\right)+e_{i j}
$$

where $V\left(h_{i j}, \boldsymbol{Z}_{i}, \tau\right) \equiv U\left(W_{i} h_{i j}-R\left(W_{i} h_{i j}, \boldsymbol{Z}_{i}, \tau\right), T-h_{i j} \mid \boldsymbol{Z}_{i}\right)$.

On the other hand, couple $i$ faces $J \times J$ pairs of labor supply $\left(h_{i j}{ }^{m}, h_{i s}{ }^{f}\right)$ with $j=1$, $\ldots, J$ and $s=1, \ldots, J$. This household is unitary and has a common utility function

$$
U_{i j s}=U^{C}\left(c_{i}, l_{i j}^{m}, l_{i s}^{f} \mid \boldsymbol{Z}_{i}^{C}\right)+e_{i j s}
$$

where $U^{C}(\cdot)$ is increasing in consumption $c_{i}$, husband's leisure $l_{i j}{ }^{m} \equiv T-h_{i j}{ }^{m}$, and wife's leisure $l_{i s}^{f} \equiv T-h_{i j}^{f}$, and $e_{i j s}$ is a choice-specific error $e_{i j s} \equiv e\left(h_{i j}{ }^{m}, h_{i s}{ }^{f}\right)$. Superscripted household characteristics $Z^{C}$ allows for cases where variables different from those in $\boldsymbol{Z}$ exist for single households. If the tax liability is interdependent between the couple, the total liability may be expressed as

$$
R_{i}=R^{C}\left(W_{i}^{m} h_{i j}^{m}, W_{i}^{f} h_{i j}^{f}, Z_{i}, \boldsymbol{\tau}\right)
$$

where $W_{i}^{m}$ and $W_{i}^{f}$ are the husband's and the wife's gross wage rates respectively. Then, the consumption is

$$
c_{i}=W_{i j}^{m} h_{i j}^{m}+W_{i j}^{f} h_{i s}^{f}-R^{C}\left(W_{i j}^{m} h_{i j}^{m}, W_{i j}^{f} h_{i s}^{f}, \boldsymbol{Z}_{i}, \boldsymbol{\tau}\right) .
$$

Choosing a pair $\left(h_{i j}{ }^{m}, h_{i s}{ }^{f}\right)$ then yields a utility level

$$
U_{i j s}=V^{C}\left(h_{i j}^{m}, h_{i s}^{f}, Z_{i}, \boldsymbol{\tau}\right)+e_{i j s}
$$

where $V^{C}\left(h_{i j}{ }^{m}, h_{i s}^{f}, \boldsymbol{Z}_{i}, \tau\right) \equiv U^{C}\left(W_{i}^{m} h_{i i}{ }^{m}+W_{i}^{f} h_{i s}{ }^{w}-R^{C}\left(h_{i j}{ }^{m}, h_{i s}{ }^{f}, Z_{i}, \tau\right), T-h_{i j}{ }^{m}, T-h_{i s}{ }^{f} \mid Z_{i}\right)$.

\subsection{The SMCF}

The literature conceptually defines the SMCF as a ratio of the reduction in social welfare $S$ (normalized in monetary units) to a concurrent unit increase in revenue $R$ (Dahlby 1998, Sandmo 1998, Liu 2006). While previous studies have expressed the SMCF in several forms, Bessho and Hayashi (2013) expressed it as a sum of individual MCFs (IMCFs) that are twice weighted with distributional weights $\beta_{i}$ and changes in tax 
liability share $\left(\mathrm{d} R_{i} / \mathrm{d} R\right)$. Thus,

$$
S M C F \equiv \sum_{i=1}^{N} \beta_{i} \cdot \frac{d R_{i}}{d R} \cdot\left(-\frac{d U_{i} / \lambda_{i}}{d R_{i}}\right)
$$

where $R \equiv \sum_{i} R_{i}$ is the total tax liability, $\lambda_{i}$ is the marginal utility of income, and $-\mathrm{d}\left(U_{i} / \lambda_{i}\right) / \mathrm{d} R_{i}$ is the IMCF and is defined as the reduction in individual utility caused by a unit increase in tax liability (Bessho and Hayashi 2013). While this SMCF formula ${ }^{2}$ presumes a continuous labor supply, the DCM of labor supply presumes discrete labor choices. We thus define the SMCF in discrete terms as

$$
S M C F \equiv \sum_{i=1}^{N} \beta_{i} \cdot \frac{\Delta R_{i}}{\Delta R} \cdot I M C F_{i}
$$

Note that the IMCF is now

$$
I M C F_{i}=-\frac{\left(U_{i}^{1}-U_{i}^{0}\right) / \lambda_{i}}{R_{i}^{1}-R_{i}^{0}}
$$

where we assume a tax change that causes the tax liability of household $i$ to increase from $R_{i}^{0}$ to $R_{i}{ }^{1}$, which reduces the household's utility level from $U_{i}^{0}$ to $U_{i}{ }^{1}$. The "marginal" utility of income $\lambda_{i}$ is also redefined as a discrete quantity. Three elements need to be estimated: the IMCFs, changes in revenue share, and distributional weights.

\subsection{The IMCF and Changes in Revenue Share}

We base our calculation of the IMCFs as well as changes in revenue share on the behavioral DCM micro-simulation (Creedy and Kalb 2005, 2006). To obtain the two quantities, we calibrate the unobserved random component of (1). We draw a vector with $J$ elements from the I-EV distribution and find the "successful draw," a vector $\boldsymbol{e}_{i}{ }^{k} \equiv$ $\left[e_{i 1}{ }^{k}, e_{i 2}{ }^{k}, \ldots, e_{i J}{ }^{k}\right]$ that makes observed labor choice $h_{i}=h_{i^{*}}$ optimal. With this draw and the estimated structural element of (1), we obtain the utility $U_{i j}{ }^{0 k} \equiv U\left(h_{i}, Z_{i}\right)+e_{i *}{ }^{k}$ and

\footnotetext{
${ }^{2}$ We follow Dahlby (1998) to set aside the revenue effect of public services. We therefore fix the level of public services in our analysis such that it does not appear in our expression of the utility function.
} 
the tax liability $R_{i}^{0}=R\left(h_{i}, Z_{i}\right)$ before the tax change. We also simulate the corresponding quantities after the tax change as $U_{i j}{ }^{1 k} \equiv U\left(h_{i * *}{ }^{k}, \boldsymbol{Z}_{i}\right)+e^{* * *}{ }^{k}$ and $R_{i}{ }^{1 k}=R\left(h^{* * *}, \boldsymbol{Z}_{i}\right)$, where $e_{i^{* *}{ }^{k}}$ is the element in $\boldsymbol{e}_{i}^{k}$ that corresponds to the optimal choice after the change. We then obtain $\lambda_{i}^{k}$ by slightly increasing nonlabor income in a lump-sum manner conditional on $\boldsymbol{e}_{i}{ }^{k}$. These quantities together yield the simulated IMCF and the SMCF as follows:

$$
\begin{aligned}
& I M C F_{i}^{k}=-\frac{\left(U_{i}^{1 k}-U_{i}^{0 k}\right) / \lambda_{i}^{k}}{R_{i}^{1 k}-R_{i}^{0}} \text { and } \\
& S M C F^{k}=\sum_{i=1}^{N} \beta_{i} \frac{R_{i}^{1 k}-R_{i}^{0}}{\sum_{i=1}^{N}\left(R_{i}^{1 k}-R_{i}^{0}\right)} I M C F_{i}^{k} .
\end{aligned}
$$

With the exception of the distributional weights (which we elaborate on in Section 2.4), the values of tax liability changes $\left(R_{i}{ }^{k}-R_{i}{ }^{0 k}\right)$ and the IMCFs depend on a given $\boldsymbol{e}_{i}{ }^{k}$. Since their values vary by a draw of $\boldsymbol{e}_{i}{ }^{k}$, so does the value of (9). To account for this, we generate $K \boldsymbol{e}_{i}{ }^{k}$ s that yield $K$ values of (10). We could then use these $K$ estimates to characterize the empirical distribution of (10) with its average $\left(\sum_{k} S M C F_{i}{ }^{k} / K\right)$ and its quartiles. We emphasize here that both formulations of (9) and (10) allow for labor supply responses along both the intensive and the extensive margins on an individual basis. This is because the simulation allows for cases where the tax change induces a change in labor supply from zero to a positive value.

\subsection{Distributional weights}

To aggregate individual welfare, the literature uses the Bergson-Samuelson social welfare function (BS-SWF) $S=S(\boldsymbol{U})$, where $\boldsymbol{U}$ is a vector of household utilities. Many empirical (and simulation) studies specify the BS-SWF in the constant elasticity of substitution (CES) form as 


$$
S=\frac{1}{1-\theta} \sum_{i=1}^{N} U_{i}^{1-\rho}
$$

where $\rho$ measures the degree of inequality aversion. From (11), we derive the distributional weights for the SMCF as

$$
\beta_{i}=\lambda_{i} \cdot U_{i}^{-\rho} .
$$

If we restrict our analysis to single-member households, we could simply quantify the level of $U_{i}$ with preference parameter estimates and obtain (12). However, such a measure of individual welfare may not be comparable among the different types of households. The current set up utilizes different forms of utility function with different sets of preference parameters and household characteristics. We are thus not sure if we can validly compare utilities across such different types of households and aggregate them without adjustments.

To accommodate this difficulty, we use three alternate aggregation methods. The first two methods base themselves on analogues of (11):

$$
S=\frac{1}{1-\theta} \sum_{i-1}^{N} y_{i}^{1-\rho}
$$

where $y_{i}$ is an index of observed income. ${ }^{3}$ This yields distributional weight $\beta_{i}=y_{i}{ }^{-\rho}$, which is popular in the literature (Dodgson 1980, 1983, Brent 1984, Poapongsakorn et al. 2000, Creedy et al. 2011). While we may not have a firm theoretical foundation for (13), ${ }^{4}$ we nonetheless use (13) with what Creedy et al. (2011) call "full income" $M_{i}$, or the after-tax income that a household can earn when it uses the maximum hours of time

\footnotetext{
${ }^{3}$ Dodgson (1980, 1983) used household income after all taxes and benefits normalized by corresponding average quantity and further adjusted with the equivalent scales. Poapongsakorn et al. (2000) used after-tax income normalized by the corresponding quantity for the highest income group. Creedy et al. (2011) used what they called "full income" (see footnote 7).

${ }^{4}$ We can derive $\beta_{i}=y_{i}^{-\theta}$ from (11) if the preferences are homothetic and households face identical prices. However, if progressive taxation is in place, the weight is no longer justifiable, as leisure prices are no longer identical, except when the BS-SWF is Nash $(\theta=1)$. See Bessho and Hayashi (2013) for more details.
} 
endowment. ${ }^{5}$ We may then want to adjust (13) so that it allows for the difference in household size. We take two routes. First, we adjust the full income with the square root equivalent scale $n_{i}^{1 / 2}$, where $n_{i}$ is the number of household members. This yields the household size adjusted full income $y_{i} \equiv n_{i}{ }^{1 / 2} M_{i}$ and the corresponding distributional weight

$$
\beta_{i}=\left(n_{i}^{1 / 2} M_{i}\right)^{-\rho}
$$

Second, we start with the household size adjusted per capita full income $m_{i} \equiv M_{i} / n_{i}{ }^{1 / 2}$, i.e., full income deflated by the root equivalent scale and further divided by household size. With this index, we set the $i$-th contribution in (13) as a household equivalent by deflating $m_{i}^{-\rho}=\left(M_{i} / n_{i}^{1 / 2}\right)^{-\rho}$ by $n_{i}^{1 / 2}$, so that we have another distributional weight

$$
\beta_{i}=n_{i}^{(1+\rho) / 2} \cdot M_{i}^{-\rho}
$$

As the last social weighting, we utilize the metric by Fleurbaey et al. (2013), namely,

$$
E=\frac{1}{1-\rho} \sum_{i=1}^{N}\left(c_{i}^{*}\right)^{1-\rho}
$$

where $c^{*}$ is an equivalent income that replaces individual utility $U_{i}$ in (11). Fleurbaey et al. (2013) characterized the properties of (16) as follows. First, (16) satisfies the Pareto principle (i.e., respects individual preferences). ${ }^{6}$ Second, since the equivalent income is in monetary units, the metric is comparable with quantity in monetary units (such as the IMCFs). Third, (16) is also applicable even when individual utilities are not comparable, since it is non-welfarist as it bases its ordering on ordinal and noncomparable preferences.

For the current case, the equivalent income $\left(c^{*}\right)$ is the amount of numeraire $c$ that

\footnotetext{
${ }^{5}$ We then define $M_{i} \equiv W_{i} T+A_{i}-R_{i}$ for a single-member household, and $M_{i} \equiv\left(W_{i}^{m}+W_{i}^{f}\right) \cdot T+A_{i}-R_{i}^{C}$ for a couple, where $A_{i}$ is nonlabor income.

${ }^{6}$ Fleurbaey et al. (2013) originally applied this valuation to the health policy. In this study, we propose an application of their metric to the leisure-consumption choice, which coincides with the Rente criterion of Decoster and Haan (2010) and the intercept income of Preston and Walker (1999).
} 
combined with the maximum consumption of leisure (i.e., no labor supply) yields the same utility level as that obtained by a household consuming the realized bundle $\left(c_{i}, l_{i}\right)$. Thus, we can implicitly define the equivalent income for a single household as

$$
U\left(c_{i}, l_{i j} \mid \boldsymbol{Z}_{i}\right)=U\left(c_{i}^{*}, T \mid \boldsymbol{Z}_{i}\right)
$$

where $e_{i j}$ in (2) cancels out and does not affect the equivalent income. We can then express the equivalent income as a function

$$
c_{i}^{*}=c_{i}^{*}\left(c_{i}, l_{i j}, T, \boldsymbol{Z}_{i}\right) .
$$

We can derive a distributional weight from (16) and (17) as

$$
\beta_{i}=\left[c_{i}^{*}\left(c_{i}, l_{i j}, T, \boldsymbol{Z}_{i}\right)\right]^{-\rho} \cdot \frac{\partial c_{i}^{*}}{\partial c_{i}}
$$

where the implicit function theorem shows $\partial c_{i}{ }^{*} / \partial x_{i}=\left[\partial U\left(c_{i}, l_{i j}\right) / \partial c_{i}\right] /\left[\partial U\left(c_{i}{ }^{*}, T\right) / \partial c_{i}\right]$. Once we specify $U(\cdot)$ in a quadratic form (see Section 3), it is straightforward to obtain $c_{i}^{*}$ and $\partial c_{i}{ }^{*} / \partial c_{i}$. For couples, the procedure is analogous and obvious.

\section{Empirical Implementation}

This section applies the technique explained in Section 2 to the 1999 tax reform in Japan. In particular, we evaluate the tax reform by obtaining the simulated distributions of (10) that correspond to the three distributional weights (14), (15), and (18).

\subsection{Specifications}

We specify the model in a log-quadratic form with labor market participation costs. For singles, we specify the structural part of (1) as

$$
\begin{aligned}
U\left(c_{i}, T-h_{i} \mid \boldsymbol{Z}_{i}\right) & =\alpha_{c i} \cdot \ln \left(c_{i}\right)+\alpha_{l i} \cdot \ln \left(T-h_{i}\right) \\
& +\gamma_{c c}\left[\ln \left(c_{i}\right)\right]^{2}+\gamma_{l l}\left[\ln \left(T-h_{i}\right)\right]^{2}+\gamma_{c l} \ln \left(c_{i}\right) \cdot \ln \left(T-h_{i}\right) \\
& +\phi_{i} \cdot 1\left\{h_{i}>0\right\}
\end{aligned}
$$

where the $\alpha$ and $\gamma$ terms are parameters. The coefficient $\phi$ in the last term is the fixed 
cost of labor market participation, which should take a negative value. We allow household characteristics $Z_{i}$ to affect the coefficients on consumption and leisure as

$$
\alpha_{n i}=\alpha_{n 0}+\alpha_{n}^{\prime} Z_{i}
$$

for $n=c$ and $l$, where $\alpha_{n}$ is a coefficient vector. For married couples, we specify the structural part of (4) as

$$
\begin{aligned}
U^{C}\left(c_{i}, T-h_{i}^{m}, T-h_{i}^{f}\right. & \left.\mid Z_{i}^{C}\right)=\alpha_{c i}^{C} \cdot \ln \left(c_{i}\right)+\alpha_{m i}^{C} \cdot \ln \left(T-h_{i}^{m}\right)+\alpha_{f i}^{C} \cdot \ln \left(T-h_{i}^{f}\right)+ \\
& +\gamma_{c c}^{C}\left[\ln \left(c_{i}\right)\right]^{2}+\gamma_{m m}^{C}\left[\ln \left(T-h_{i}^{m}\right)\right]^{2}+\gamma_{f f}^{C}\left[\ln \left(T-h_{i}^{f}\right)\right]^{2} \\
& +\gamma_{c m}^{C} \ln \left(c_{i}\right) \cdot \ln \left(T-h_{i}^{m}\right)+\gamma_{c f}^{C} \ln \left(c_{i}\right) \cdot \ln \left(T-h_{i}^{f}\right) \\
& +\gamma_{m f}^{C} \ln \left(T-h_{i}^{m}\right) \cdot \ln \left(T-h_{i}^{f}\right) \\
& +\phi_{F m}^{C} \cdot 1\left\{h_{i}^{m}>0\right\}+\phi_{F f}^{C} \cdot 1\left\{h_{i}^{f}>0\right\}
\end{aligned}
$$

where the $\alpha^{C}$ and $\gamma^{C}$ terms are parameters. We again allow household characteristics $\boldsymbol{Z}_{i}^{C}$ to affect the coefficients

$$
\alpha_{n i}^{C}=\alpha_{n 0}^{C}+\alpha_{i}^{C^{\prime}} Z_{i}^{C}
$$

for $n=c, m$, and $f$, where $\alpha_{i}^{C}$ is a coefficient vector. The fixed costs of labor market participation now depend on the number of children aged six years and younger $\left(k_{i d s}\right)$ :

$$
\phi_{F s}^{C}=\lambda_{F s} \cdot k i d s_{i}
$$

for $s=m$ and $f$.

Several studies assume that some or all of the linear term coefficients (19b) and (20b) contain additive unobservable random terms $\xi$ as

$$
\alpha_{n i}=\alpha_{n 0}+\alpha_{n}^{\prime} Z_{i}+\xi_{n i} \quad \text { and }
$$

$$
\alpha_{n i}^{C}=\alpha_{n 0}^{C}+\alpha_{i}^{C \prime} Z_{i}^{C}+\xi_{n i}^{C}
$$

where $\xi$ is the unobserved heterogeneity. There are three patterns of such randomness. They assume (19b') or (20b') for the coefficients on (i) consumption $(n=c)$ (Blundell et 
al. 1999, 2000, Haan 2006, Gerfin and Leu 2007, Bargain 2009), (ii) leisure $(n=l)$ (Van

Soest 1995, Van Soest and Das 2001, Gong and Van Soest 2002, Vermeulen 2006, Callan et al. 2009, Shalhoub 2011) ${ }^{7}$, and (iii) both consumption and leisure $(n=c, l)$ (Duncan and Harris 2002, Brewer et al. 2006, Mych et al. 2006, Brink et al. 2007, Baldini and Pacifico 2009). ${ }^{8}$

\subsection{Sample and data}

To evaluate the tax reform in 1999 with the SMCF, we utilize the data from the Employment Status Survey (ESS) conducted by the Statistical Bureau in 1997, which is the year closest to 1999. We focus on the two samples of households (singles and married couples with or without children) with their heads aged between 25 and 55 years. We exclude households whose earners are (a) self-employed workers, (b) board members of private companies or non-profit organizations, (c) family workers at unincorporated companies, and (d) unemployed because of illness, from the samples. We also exclude households whose heads had changed their residences or jobs, and those who bore children within the one year that predated the ESS. These exclusions result in final samples of 19,735 households of singles and 43,011 households of married couples.

The ESS codes hours worked into interval data. Using these intervals, we set up eight choices of hours worked per year as shown in Table 1. Married couples thus have $8 \times 8=64$ choices. We set the maximum hours of labor per year as $T=16 \times 365=$ 5,840 .

\section{Table 1}

Tables $2 \mathrm{a}$ and $2 \mathrm{~b}$ list sample statistics. The household characteristics for singles $\boldsymbol{Z}_{i}$

\footnotetext{
7 Vermeulen (2006) and Shalhoub (2011) also allowed the random coefficient on the squared value of leisure.

8 Duncan and Harris (2002), Brewer et al. (2005), and Callan et al. (2009) also considered unobserved heterogeneity in fixed cost $(20 \mathrm{c})$.
} 
consist of ten dummies for five age groups $(30-34,35-39,40-44,45-49$, and 50-54 years), gender (female), residence in one of the three urban areas (Greater Tokyo, Chukyo, and Kinki), and three educational backgrounds (senior high school graduate, junior college graduate, or graduate from a university or higher institution). The household characteristics for couples $\boldsymbol{Z}_{i}^{C}$ consist of residence in one of the urban areas (one dummy), five age groups for husband and wife (10 dummies), educational backgrounds for husband and wife (6 dummies), and three child-related variables (numbers of children aged 6 years and below, aged 7-14 years, and aged 15 years and above).

\section{Tables 2a and $2 b$}

The data for gross wages are the fitted values from wage regressions performed separately for men and women. Since the ESS codes hours worked and labor income in intervals, we first construct raw gross wage rates using the middle values of these intervals. We then regress the natural logarithm of this raw wage rate on household characteristics of the dummies for age groups, educational backgrounds, and residence in urban areas. The regressors also include interaction terms among these dummies (interactions between age and education; education and residence; residence and age; and age, education, and residence). We "heckit" the wage equations with the residuals as the exclusion restriction, from an OLS regression of nonlabor household income on the same set of variables used for the wage regression. Assuming that the error term for the wage equations has a normal density, we obtain the values for $W_{i}$ as $\exp \left(\omega_{i}+s^{2} / 2\right)$, where $\omega_{i}$ is the fitted value from the wage equation, and $s^{2}$ is the sample estimate for the variance of the error term.

We obtain a household's after-tax income (consumption) $c_{i}$ for each alternative in the choice set by calculating tax liabilities as well as cash benefits that correspond to the level of labor supply and to the relevant household characteristics. Appendix B offers 
the details of the tax liabilities and cash benefits that we consider in this exercise.

\section{Estimation Results}

\subsection{Preference Parameters}

The assumption of random coefficients (19b') and (20b') requires us to formulate the discrete choice as a mixture model and estimate its parameters by maximizing the value of the simulated log-likelihood. For each of the three patterns of the unobserved heterogeneity, we attempt to estimate the models by alternatively employing the standard mixed logit model (e.g., Van Soest 1995) and the latent class model (e.g., Hoynes 1996). ${ }^{9}$ However, we only succeed in achieving convergence in the parameter estimates when we use the mixed logit model with (19b') and (20b') only for the consumption coefficient. As pointed out by Pacifico (2013), this may be because of the computational difficulties that rise with gradient-based maximization algorithms when estimating random coefficient models.

Table $3 \mathrm{a}$ lists the estimation results with and without the random coefficients for singles, along with the estimates for four cases of different combinations of household characteristics (Models A1-A4). The estimates generally differ between the random and nonrandom models. In addition, we find evidence that the unobserved heterogeneity exists as the estimated standard deviation for the random consumption coefficient is statistically different from zero at the standard levels of significance.

\section{Table 3a}

Table $3 b$ provides the estimation results of the five models for couples with different combinations of household characteristics (Models B1-B5). In contrast to the singles cases, we find no evidence of unobserved heterogeneity in all the five cases, as the estimated standard deviations of the random terms are very small relative to the

\footnotetext{
${ }^{9}$ When calculating the simulated maximum likelihood, we set the number of replications as 100 and assumed a normal distribution of the random coefficients for the mixed logit estimation.
} 
values of their standard errors. Several previous studies have reported this type of insignificant difference between random and nonrandom models, although they did not delineate specific reasons for such insignificance. ${ }^{10}$ In fact, our estimation of the random and nonrandom models shows no numerical differences between their corresponding estimates (including standard errors) for at least up to three digits after the decimal point (we thus do not duplicate the result for the nonrandom model in Table 3b). Since we set the initial values as the values obtained from the nonrandom model while estimating the corresponding random models, this implies that there are no gains in the score of the simulated log-likelihood from changing the initial values. There is also the possibility that this may be due to computational difficulties.

\section{Table 3b}

Given these results, we proceed with the parameter estimates from the nonrandom models for both singles and couples. We opt for the deterministic models for couples since we cannot reject them against the random models that might also entail computational difficulties. We also utilize the deterministic models for singles despite the fact that we reject them against the alternatives, simply to avail of comparable results between singles and couples. This choice for singles may be justified, since the implications of the labor supply models do not differ significantly between the nonrandom and random models with unobserved heterogeneity only on the consumption coefficient, even when the random effect is statistically significant.

Despite their frequent usage in simulation studies ${ }^{11}$, we are aware that the nonrandom models may indeed be restrictive. In addition, we could have utilized an alternative method (expectation maximization algorithm) to bypass the computational

\footnotetext{
${ }^{10}$ See Van Soest (1995), Van Soest and Das (2001), Duncan and Harris (2002), Brewer et al. (2005, 2006), Vermeulen (2006), Baldini and Pacifico (2009), Shalboub (2011). Note that Brewer et al. (2005, 2006) did find that the unobserved heterogeneity in the fixed cost term is statistically significant.

${ }^{11}$ For example, see Aaberge et al. (2004), Steiner and Wrohlich (2004, 2005), Bargain and Orsini (2006), Creedy and Kalb (2006), Fuest et al. (2008), Deconster and Haan (2010), Dagsvik et al. (2011), Peichl and Siegloch (2012), and Aaberge and Colombino (2013).
} 
difficulties that we face when we estimate the nonrandom models (Pacifico 2013). We nonetheless use the models $(19 a-b)$ and $(20 a-b)$ without unobserved heterogeneity (19b') and (20b'). We justify our usage of the deterministic models since our primal focus is not to estimate an elaborate model of labor supply, but to use them as an example of welfare analysis.

We thus test among the four nonrandom models (Models A1-A4) for singles with a series of likelihood ratio tests, and select Model A4 against which we emphatically reject each of the other three models. We analogously test among the five models (Models B1-B5) for couples, and select Model B5 against which we emphatically reject each of the other four models. In what follows, we thus use the results for Model A4 and Model B5.

The log-quadratic specifications (19a) and (20a) do not impose a priori restrictions that preferences are quasi-concave and that the marginal utility of income is positive. It is thus important to check if these conditions are satisfied. We examine these two properties by checking the positive definiteness of the matrix $H C$ of Van Soest (1995, Eq. 3) and the value of the marginal utility of income $(\mathrm{d} U / \mathrm{d} c)$ for every household in our samples. Our examination shows that almost all the households satisfy the two conditions: $H C$ is positive definite for $99.2 \%$ of singles and $99.8 \%$ of couples, and $\mathrm{d} U / \mathrm{d} c$ is positive for $98.3 \%$ of singles and $99.8 \%$ of couples.

\subsection{Elasticity}

Before we obtain the SMCF estimates, we present the simulated elasticity of labor supply. Again, we use Model A4 for singles and Model B5 for couples. Following the literature (Creedy and Kalb 2005, 2006; Bargain et al. 2011), we obtain the elasticity estimates by changing the gross wage rate by $1 \%$ and simulating resultant labor supply changes for each observation. We repeat simulating such individual labor supply responses for each of the 150 successful draws and average the results over the draws. 
Table 4 presents the simulated elasticity along the intensive margin for those households whose initial labor supply choices were positive $\left(h_{i}>0\right)$. Overall, the labor responses along the intensive margins are small. As listed in the first row of Table 4, the gross wage elasticity averaged across singles is .016, which is smaller than analogous elasticity for European countries (Bargain et al. 2012, Table A3). The second and fourth rows list the own-wage elasticity for husbands and wives. The average own-wage elasticity is .042 for husbands and .063 for wives. Both values are smaller than estimates provided by previous DCM studies, ranging from .08 to .46 for husbands and from .08 to .65 for wives (Bargain et al. 2012, Tables A1 and A2). However, our results still conform to those of previous studies, in that females are more responsive than males to changes in own wages.

The average values for the cross-elasticity for husbands (the third row in Table 4) and wives (the fifth row) are -.008 and .130 , which implies that, on average, a husband responds to an increase in his wife's wage by reducing his working hours, while a wife responds to an increase in her husband's wage in the opposite direction. While the survey by Bargain et al. (2012) did not list the analogous values, Van Soest (1995) provided such estimates for three variations of his model. As in our case, he showed that male labor supply responds negatively to female wage rate, although our average $(-.008)$ is somewhat smaller in absolute value than the smallest of the three median estimates (-.010). On the other hand, he also showed that the medium response of female to her husband's wage rate varies over the three models $(-.171, .005$, and .051$)$. Our elasticity estimate (.130) is more than twice as large than the highest of the three medians.

Table 4 also lists in parentheses the elasticities calculated analytically with the I-EV distribution. Their averages are not much different from simulated counterparts, except the average for single households, which is smaller than the simulated value. In 
addition, their standard deviations are larger.

\section{Table 4}

We also calculate the simulated values for participation elasticity. A $1 \%$ increase in gross wages yields $K(=150)$ sets of simulated labor choices of $N$ households $\left\{h_{1}{ }^{k}\right.$, $\left.h_{2 *}{ }^{k}, \ldots, h_{N^{*}}{ }^{k}\right\}$, where $*$ denotes the simulated optical choice. The $k$-th simulation yields the participation rate $\sum_{i} 1\left\{h_{i^{*}}{ }^{k}>0\right\} / N$ and its change $\Delta P_{k} \equiv \sum_{i}\left(1\left\{h_{i^{*}}{ }^{k}>0\right\} / N\right)-P_{k}$, where $\left.P_{k} \equiv \sum_{i} 1\left\{h_{i}>0\right\}\right) / N$. With the participation elasticity $\eta_{k} \equiv 100 \times \Delta P_{k} / P_{k}$ for the $k$-th round, we obtain its empirical average $\eta \equiv \sum_{k} \eta_{k} / K$. The participation elasticity for singles is .039 , which (as expected) is larger than the corresponding elasticity along the intensive margins (-.023). This value is within the range of elasticity (.01-1.8) provided by previous studies (Bargain et al. 2012, Table A3). The elasticity of wife's participation is .042 for her own wage and .084 for her husband's wage. Compared with the corresponding values of .020 and .045 along the intensive margin, the participation effects are again larger. On the other hand, the elasticity of husband's participation is .017 for his wage and -.003 for his wife's wage. The former is smaller and the latter is larger than the corresponding values along the intensive margin (.042 and -.008, respectively). Meanwhile, the literature shows that the own-wage effects range from .04-1.51 for wives and from .00-.26 for husbands (Bargain et al. 2012, Tables A1 and $\mathrm{A} 2$ ).

While these values of elasticities - both the intensive and extensive margins - are within the ranges estimated by previous studies, they are indeed located at the lower tails of the estimates. In the ensuing analysis with the SMCF, therefore, we also examine how the result of the welfare analysis changes if we increase the number of households that reduce their labor supply after a rise in personal income tax rate. This increases the average value of labor supply elasticities and provides a robust check for our welfare analysis. 


\subsection{SMCF}

We obtain the SMCF (10) by increasing each of the five national marginal tax rates by $1 \%$ point. $^{12}$ For the distributional weights, we consider (14), (15), and (16) with three values of inequality aversion: $\rho=.4, .8$, and 1.2. We also consider the cases with two ad hoc distributional weights $n_{i}$ and $n_{i}^{1 / 2}$, where the latter equals (16) when $\rho=$ 0 . Our simulation yields 150 values of (10), with which we characterize its average as $\sum_{k} S M C F_{i}^{k} / K$ as well as its empirical distribution.

The unshaded cells in Table 5 show the average SMCFs for each income bracket, where we multiply the SMCFs for (14) and (15) by 100 because of the small scales of their original values. The table shows that the average SMCF for a $1 \%$ increase in the top marginal tax rate is the smallest among the five income brackets for any of the distributional weights, and it decreases in value as the tax bracket increases. Since, as we have mentioned, our labor supply elasticities are lower than those estimated in comparable studies, we examine how the SMCFs change if we make the aggregate labor supply more responsive. For this purpose, we artificially multiply households in our sample that reduce their labor supply after the tax increase and recalculate the SMCFs accordingly. We use the multiplier of 13 so as to obtain the average elasticity of labor supply for couples, which roughly equals to .4, allowing for both the intensive and extensive margins. ${ }^{13}$ The shaded cells in Table 5 list the recalculated SMCFs, ${ }^{14}$ which show that our qualitative conclusion is robust to the increase in labor supply responses. In addition, even the quantitative results are also similar when the SMCFs are based on

\footnotetext{
${ }^{12}$ While we only consider national income taxes, we do allow for other income taxes, such as local income taxes and social security premiums, in order to calculate the effective marginal tax rates and brackets (as explained in Section 3.2). As such, there are more than five effective income brackets when all the taxes are considered. Note also that we excluded a small number of observations (.7\%) with anomalous data rendering negative values of $\partial c_{i}^{*} / \partial c_{i}$.

${ }^{13}$ We use the labor supply elasticity of .4 as the "normal" degree of labor response based on the survey by Bargain et al. (2012).

${ }_{14}$ While calculating the SMCFs, we obtain the equivalent effect of this multiplication by placing an additional weight $\phi_{i}$ on $\beta_{i}$, which takes $\phi_{i}=13 /\left[13 N^{*}+\left(N-N^{*}\right)\right]$ if household $i$ reduces labor supply and $\phi_{i}=$ $13 /\left[13 N^{*}+\left(N-N^{*}\right)\right]$ otherwise. Note that $N$ is the total number of households, and $N^{*}$ is the number of households that increased their labor supply.
} 
weight (16) (as in Fleurbaey et al. (2013)) and the last simple weights with $n_{i}$ and $n_{i}{ }^{1 / 2}{ }^{15}$ The other two weights (14-15) however yield larger values when the labor supply is more responsive.

\section{Table 5}

We may also assess the SMCFs by looking at their empirical distributions. The panels in Figure 1 show the empirical distributions of the simulated SMCFs for the five income brackets with different distributional weights. The box plot displays boxes bordered at the 25th and 75th percentiles of the simulated SMCFs with a median line. Whiskers extend from the box to the upper and lower adjacent values ${ }^{16}$ marked with corresponding adjacent (horizontal) lines. The plot regards values exceeding the adjacent lines as outliners and indicates them with dots. From Figure 1, we make the following observations. First, the relative positions of the SMCFs over the five income brackets are rather robust over the different types of distributional weights and the different degrees of inequality aversion. Second, for every panel, none of the SMCFs in the first three brackets overlaps with those in the other two brackets. For any of the distributional weights considered in this study, any simulated SMCF in a given bracket is larger than that in a higher bracket among the first three brackets. Third, setting aside several outliners marked with dots, the upper adjacent line of the fourth-bracket SMCFs exceeds the lower adjacent line of the third-bracket SMCFs in every panel, while the ceiling of the box (the 3rd quartile) for the fourth-bracket SMCFs does not. Lastly, setting aside the outliners again, the SMCFs for the top bracket do not overlap any values of the SMCFs for the other four brackets in any panels, although the largest outliners well exceed the SMCFs in the third income bracket.

\footnotetext{
15 These results might not be so surprising since the qualitative conclusion depends on the relative sizes of the SMCFs across income brackets. Multiplying the responsive households by the same number should not change such relative comparisons since it would not change their relative proportions over the income brackets either.

${ }^{16}$ The upper and lower adjacent values are given as upper quartile $+1.5 \times$ (upper quartile - lower quartile) and lower quartile $-1.5 \times$ (upper quartile - lower quartile), respectively.
} 
Since the SMCFs in the top two brackets have some salient outliners, we may look at their histograms directly. We construct histograms for Panel C1-C3 with Fleurbaey's distributional weight (16), which the literature argues is the most appropriate weight for comparing different types of households. The panels in Figure 2 show the distributions of the simulated SMCFs for three inequality aversions. As expected for Panels $\mathrm{C} 1-\mathrm{C} 3$ in Figure 1, the relative positions among the distributions of the SMCFs for different brackets are similar across the three values of inequality aversion. Since the outliners for the top bracket are rather rare, we could argue that the SMCF for the top bracket is often the smallest among the five brackets. We also observe that the upper tails of the fourth-bracket SMCFs overlap the lower tails of the third-bracket SMCFs when the degree of inequality aversion is at its highest. However, the overlap is rather infrequent. In addition, the average values (Table 5), the mediums (Figure 1), and the modes (Figure 2) for the SMCFs decrease with the increasing order of income bracket.

\section{Figures 1 and 2}

Given these observations, it would be safe to conclude that the SMCF is lower for an upper income bracket. Therefore, according to our analysis, the 1999 reform of national income tax that reduced the top marginal tax rates from $50 \%$ to $40 \%$ and the second top marginal tax rate from $40 \%$ to $30 \%$ was not advisable. We could then argue that the Japanese government should have reduced the marginal tax rates in the lower income brackets rather than hold them constant, as it did in the 1999 reform. In other words, the reform should have made the Japanese tax system more progressive.

\section{Conclusion}

This study proposed a method to obtain the SMCF that allows for heterogeneity on an individual basis and labor supply responses along both the extensive and the 
intensive margins. To demonstrate our methodology, we took the example of the 1999 national income tax reform in Japan and evaluated it by estimating the SMCF for changing marginal tax rates in different income brackets before the reform occurred. Thus, we estimated the DCM of labor supply using a data set of Japanese households in 1997. We also delineated a procedure to obtain an analog of the SMCF that allows for labor supply responses along both the intensive and the extensive margins. We calculated such SMCFs using a micro-simulation method that utilizes the DCM estimates for household preferences as well as a pseudo-random number generator. Based on the simulated SMCFs evaluated using various distributional weights, we found that the value of the SMCF for a $1 \%$ increase in the marginal tax rate in any given income bracket decreases as the bracket moves from the bottom-most to the fourth bracket. This would suggest that the national government should have made the Japanese income tax system more progressive in the 1999 tax reform. Our method is also transferrable to tax reforms in other countries as well.

Our analysis, of course, suffers from some limitations. First, our DCM of labor supply was static, and thus, it did not allow for a dynamic choice of labor supply. Second, we assumed a collective household whose members cooperatively maximize their household utility and ignored strategic interactions within a household. Third, our model presumed a perfect knowledge of tax codes and did not take into consideration the tax evasion of households. Although these limitations are not straightforward to tackle in the framework of standard DCMs, they constitute avenues for future research.

\section{Acknowledgements}

We are grateful to Eckhard Janeba and two anonymous reviewers for their helpful comments and constructive suggestions. We also thank Robin Boadway, Bev Dahlby, Toshihiro Ihori, Shigeki Kunieda, and Yukihiro Nishimura for their valuable advice and 
help in the preliminary stages of this project. We would like to acknowledge the Research Centre for Information and Statistics of Social Science at the Institute of Economic Research at Hitotsubashi University for providing micro-level data from the Employment Status Survey for 1997. Bessho is financially supported by the Grant-in-Aid for Scientific Research (Grant-in-Aid for Young Scientists B-19730215). Hayashi acknowledges financial support from the Nomura Foundation, the Seimei Foundation, and the Center for International Research on the Japanese Economy at the University of Tokyo.

\section{References}

Aaberge, R., Colombino, U., Strøm, S. (2004) Do more equal slices shrink the cake? An empirical investigation of tax-transfer reform proposal in Italy. Journal of Population Economics 17(4), 767-785.

Aaberge, R., Colombino, U. (2013) Using a microeconometric model of household labour supply to design optimal income taxes, Scandinavian Journal of Economics 115(2), 449-475.

Baldini, M., Pacifico, D. (2009) The recent reforms of the Italian personal income tax: Distributive and efficiency effects. Rivista Italiana Degli Economisti 14(1), 191-218.

Bargain, O.,(2009) Flexible labor supply models. Economic Letters 105(1), 103-105.

Bargain, O., Orsini, K. (2006) In-work policies in Europe: Killing two birds with one stone? Labour Economics 13(6), 667-697.

Bargain, O., Orsini, K., Peichl, A. (2012) Comparing labor supply elasticities in Europe and the US. IZA Discussion Paper Series No. 6753, The Institute for the Study of Labor (IZA), forthcoming in Journal of Human Resources.

Bessho, S., Hayashi, M. (2005) Economic studies of taxation in Japan: The case of personal income taxes. Journal of Asian Economics 16(6), 956-972.

Bessho, S., Hayashi, M. (2011) Labor supply response and preferences specification: Estimates for prime-age males in Japan. Journal of Asian Economics 22(5), 398-411.

Bessho, S., Hayashi, M. (2013) Estimating the social marginal cost of public funds: A micro-data approach. Public Finance Review 41(3), 360-385.

Blundell, R., Duncan, A., McCrae, J., Meghir, C. (1999) Evaluating in-work benefit reform: the working families' tax credit. Paper presented at the Joint Center for Poverty Research Conference, Northwestern University, November, 1999.

Blundell, R., Duncan, A., McCrae, J., Meghir, C. (2000) The labour market impact of the 
working families' tax credit. Fiscal Studies 21(1), 75-104.

Blundell, R., MaCurdy, T. (1999) Labor supply: A review of alternative approaches. In Ashenfelter, O., Card, D., (Eds.), Handbook of labor economics 3A (1559-1695). Amsterdam: Elsevier.

Brent, R. J. (1984) Use of distributional weights in cost-benefit analysis: A survey of schools. Public Finance Review 12(2), 213-230.

Brewer, M., Duncan, A., Shephard, A., Suárez, M. J. (2005) Did working families' tax credit work? The final evaluation of the impact of in-work support on parents' labour supply and take-up behavior in the UK. Final Version (available at http://www.nottingham.ac.uk/economics/ cpe/publications/Brewer_Duncan_Shephard_Suarez_2005_Labour_Economics.pdf).

Brewer, M., Duncan, A., Shephard, A., Suárez, M. J. (2006) Did working families' tax credit work? The impact of in-work support on labour supply in Great Britain. Labour Economics 13(6), 699-720.

Brink, A., Nordblom, K., Wahlberg, R. (2007) Maximum fee versus child benefit: A welfare analysis of Swedish child-care fee reform. International Tax and Public Finance 14(4), 457-480.

Callan, T., van Soest, A., Walsh, J.R. (2009) Tax structure and female labour supply: Evidence from Ireland. Labour 23(1) 1-35.

Creedy, J., Kalb, G. (2005) Discrete hours labour supply modeling: Specification, estimation and simulation. Journal of Economic Survey 19(5), 697-734.

Creedy, J., Kalb, G. (2006) Labor supply and microsimulation: the evaluation of tax policy reforms. Cheltenham, UK: Edward Elgar.

Creedy, J., Hérasult, N., Kalb, G. (2011) Measuring welfare changes in behavioral microsimulation modeling: Accounting for the random utility component. Journal of Applied Economics 14(1), 2-34.

Dahlby, B. (1998) Progressive taxation and the social marginal cost of public funds. Journal of Public Economics 67(1): 105-122.

Dahlby, B. (2008) The marginal cost of public funds: theory and applications. Cambraidge, Massachusetts: The MIT Press.

Dagsvik, J.K., Ja, Z., Orsini, K., van Camp, G. (2011) Subsidies on low-skilled workers' social security contributions: The case of Belgium. Empirical Economics 40(3), 779-806.

Decoster, A., Haan, P. (2010) Empirical welfare analysis in random utility models of labour supply, Center for Economic Studies Discussion Paper Series (DPS) 10.30. Department of Economics, KU Leuven.

Decoster, A., Swerdt, K.D., Orsini, K. (2010) A Belgian flat income tax: Effects on labour supply and income distribution. Review of Business and Economics 55(1), 23-55.

Dodgson, J. S. (1980) Social welfare functions, income distribution and welfare weight in the United Kingdom, Manchester School of Economic and Social Studies 48(1), 1-16.

Dodgson, J. S. (1983) Expenditure function estimates of the efficiency and distributive impact of indirect taxes in the United Kingdom. European Economic Review 20(1/3), 59-78. 
Duncan, A., Harris, M.N. (2002) Simulating the behavioural effects of welfare reforms among sole parents in Australia. Economic Record 78(242), 264-276.

Ericson, P., Flood, F. (2009) A microsimulation approach to an optimal Swedish income tax, IZA Discussion Paper No. 4379, The Institute for the Study of Labor (IZA).

Feldstein, M. (1976) On the theory of tax reform. Journal of Public Economics 6(1/2), 77-104.

Fleurbaey, M. (2006) Social welfare, priority to the worst-off and the dimensions of individual well-being, In: Farina, F., Savaglio, E. (Eds.), Inequality and economic integration (225-268). London: Routledge.

Fleurbaey, M. (2008) Willingness-to-pay and the equivalence approach, OPHI Working Paper 25.

Fleurbaey, M., Luchini, S., Muller, C., Schokkaert, E. (2013) Equivalent income and fair evaluation of health care. Health Economics 22(6), 711-729

Fuest, C., Peichl, A., Schaefer, T. (2008) Does a simpler income tax yield more equity and efficiency? CESifo Economic Studies 54(1), 73-97.

Gerfin, M., Leu, R. E. (2007) Evaluating the cost-effectiveness of in-work benefits: A simulation study for Switzerland. German Economic Review 8(4), 447-467.

Gong, X., Van Soest, A. (2002) Family structure and female labor supply in Mexico City. Journal of Human Resources 37(1), 163-193.

Haan, P. (2006) Much ado about nothing: Conditional logit vs. random coefficient models for estimating labour supply elasticities. Applied Economics Letters 13(4), 251-256.

Haan, P. Wrohlich, K. (2010) Optimal taxation: The design of child-related cash and in-kind benefits. German Economic Review 11(3), 278-301.

Hayashi, M. (2009) The tax system and labor supply: Regarding empirical analysis in Japan. Japanese Economy 36(1), 106-139.

Hayashi, M. (2010) Social protection in Japan: Current state and challenges, In Asher, M.G., Oum, S., Parulian, F. (Eds.), Social protection in East Asia: current state and challenges (19-54). Jakarta: Economic Research Institute for ASEAN and East Asia.

Heckman, J., Stiger, B. (1984) A method for minimizing the impact of distributional assumptions in econometric model for duration data. Econometrica 52(2), 251-320.

Hoynes, H.W. (1996) Welfare transfers in two-parent families: Labor supply and welfare Participation under AFDC-UP. Econometrica 64(2), 295-332.

Kimmel, J., Kniesner, T. (1998) New evidence on labor supply: Employment versus hours elasticities by sex and marital status. Journal of Monetary Economics 42(2), 289-301.

Kleven, H. J., Kreiner, C. T. (2006) The marginal cost of public funds: Hours of work versus labor force participation. Journal of Public Economics 90(10/11), 1955-1973.

Liu, L. (2006) Combining distributional weights and the marginal cost of funds. Public Finance Review 34(1), 60-79.

Mych, M., Bargain, O., Beblo, M., Beninger, D., Blundell, R., Carrasco, R., Chiuri, M-C., Laisney, F., Lechene, V., Longobardi, E., Moreau, N., Ruiz-Castillo, J., Vermeulen, F. (2006) The working families' tax credit and some European tax reforms in a collective 
setting. Review of Economics of the Household 4(2), 129-158.

Pacifico, D. (2013) On the role of unobserved preference heterogeneity in discrete choice models of labour supply. Empirical Economics 45(2), 929-963.

Peichl, A., Siegloch, S. (2012) Accounting for labor demand effects in structural labor supply models. Labour Economics 19(1), 129-138.

Poapongsakorn, N., Charnvitayapong, K., Laovakul, D., Suksiriserekul, S., Dahlby, B. (2000) A cost-benefit analysis of the Thailand taxpayer survey. International Tax and Public Finance 7(1), 63-82.

Preston, I., Walker, I. (1999) Welfare measurement in labour supply models with nonlinear budget constraints. Journal of Population Economics 12(3), 243-361.

Sandmo, A. (1998) Redistribution and the marginal cost of public funds. Journal of Public Economics 70(3), 365-382.

Shalhoub, M. (2011) A collective model of female labor supply: Evidence from Georgia. American Journal of Mathematical Modeling 1(1), 1-10.

Steiner, V., Wrohlich, K. (2004) Household taxation, income splitting and labor supply incentives: A microsimulation study for Germany. CESifo Economic Studies 50(3), $541-569$.

Steiner, V., Wrohlich, K. (2005) Work incentives and labor supply effects of the 'mini-jobs' in Germany. Empirica 32(1), 91-116.

Van Soest, A. (1995) Structural models of family labor supply: A discrete choice approach. Journal of Human Resources 30(1), 63-88.

Van Soest, A., Das, M. (2001) Family labor supply and proposed tax reforms in the Netherlands. De Economist 149(2), 191-218.

Vermeulen, F. (2006) A collective model for female labour supply with non-participation and taxation. Journal of Population Economics 19(1), 99-118. 


\section{Appendix A}

Appendix A explains the method of obtaining each of the components in (9) and (10). After we estimate parameters in $U(\cdot)$, we calibrate the random component $e_{i j}$ in (2) as follows.

[1] Draw a vector of $J$ random numbers that follow the I-EV distribution. Let $\boldsymbol{e}_{i}^{q} \equiv\left[e_{i 1}^{q}\right.$, $\left.e_{i 2}{ }^{q}, \ldots, e_{i J}^{q}\right]^{\prime}$ be the $q$-th draw of such a vector. This yields a set of utility levels $\boldsymbol{U}_{i}^{q}$ $\equiv\left[U_{i 1}{ }^{q}, U_{i 2}{ }^{q}, \ldots, U_{i J}{ }^{q}\right]$, where $U_{i j}{ }^{q} \equiv V\left(h_{i j}, Z_{i}, \tau\right)+e_{i j}{ }^{q}$. If observed labor choice $h_{i}$ coincides with the choice among the $J$ alternatives that picks up the maximum value in $\boldsymbol{U}_{i}^{q}$, store $\boldsymbol{e}_{i}^{q}$ as a "successful" draw. Repeat this process to obtain $K$ successful draws $\left\{\boldsymbol{e}_{i}{ }^{1}, \ldots, \boldsymbol{e}_{i}{ }^{k}, \ldots, \boldsymbol{e}_{i}{ }^{K}\right\}$.

[2] For a given successful vector draw $\boldsymbol{e}_{i}{ }^{k}$, we can construct pairs of utility level

$$
U_{i}^{0 k}=V\left(h_{i}, Z_{i}, \boldsymbol{\tau}\right)+e_{i^{*}}^{k}
$$

and individual tax liability

$$
R_{i}^{0}=R\left(W_{i} h_{i}, Z_{i}, \boldsymbol{\tau}\right)
$$

where " $j=*$ " in (A1) indicates that the choice * is optimal for a vector of $\boldsymbol{e}_{i}{ }^{k}$. Since observed choice $h_{i}$ is the optimal choice by construction, different $\boldsymbol{e}_{i}{ }^{k}$ does not affect the optimal choice and the values of $V\left(h_{i}, Z_{i}, \tau\right)$ and $R\left(W_{i} h_{i}, Z_{i}, \tau\right)$.

[3] Change the tax parameters "slightly," from $\tau$ to $\tau$. This will change the deterministic part of utility in (2) from $V\left(h_{i j}, \boldsymbol{Z}_{i}, \tau\right)$ to $V\left(h_{i j}, \boldsymbol{Z}_{i}, \tau^{1}\right)$. Using $\boldsymbol{e}_{i}^{k}$ above, we can predict a new labor choice $h_{i^{* *}}{ }^{k}$ by selecting the choice that yields the maximum values among $\left\{U_{i 1}{ }^{1 k}, U_{i 2}{ }^{1 k}, \ldots, U_{i J}{ }^{1 k}\right\}$, where $U_{i j}{ }^{1 k} \equiv V\left(h_{i j}, Z_{i}, \tau^{1}\right)+e_{i j}{ }^{k}$. The new utility and tax liability are

$$
\begin{aligned}
& U_{i}^{1 k}=V\left(h_{i * *}^{k}, Z_{i}, \tau^{1}\right)+e_{i^{* * *}}^{k} \text { and } \\
& R_{i}^{1 k}=R\left(W_{i} h_{i^{* *}}^{k}, Z_{i}, \tau^{1}\right) .
\end{aligned}
$$

[4] Simulate the "marginal" utility of income with a "small" lump-sum increase in 
nonlabor income $\Delta$, which yields $V^{\lambda}(\cdot)$. Using $\boldsymbol{e}_{i}^{k}$ again, select $U_{i^{*}}{ }^{\lambda k}=\max \left\{U_{i 1}{ }^{\lambda k}\right.$, $U_{i 2}{ }^{\lambda k}, \ldots, U_{i J}^{\lambda k}$, where $U_{i j}^{\lambda k} \equiv V^{\lambda}\left(h_{i j}, Z_{i}, \tau\right)+e_{i j}{ }^{k}$, which yields an estimate for $\lambda_{i}^{k}$ as

$$
\lambda_{i}^{k}=\frac{U_{i^{*}}^{\lambda k}-U_{i}^{0 k}}{\Delta}
$$

\section{Appendix B}

Appendix B explains our method of calculating tax liabilities and cash transfer benefits. Personal income tax liabilities consist of income tax imposed by the central government, inhabitant tax levied by local governments (prefectures and municipalities), and social insurance premiums for public pensions, health insurance, and unemployment insurance. The tax codes for FY 1997 are shown in Table A1. In calculating the tax liabilities, we make the following compromises due to data limitations. First, while local governments base their taxes on income in the previous year, we use the current income as a surrogate. Second, while local governments can change their tax rates, we use the standard uniform local tax rates as set by the national law, since most local governments adhere to the standard rates. Third, while public insurance premiums differ by place of work, we assume that combined premium rates for the three public insurances - those employed by firms with less than 1,000 employees, firms with 1,000 employees or more, and the public sector-are $13.3 \%$, $14.3 \%$, and $12.9 \%$ respectively, with specified ceilings on premium payments. Fourth, for deductions and exemptions, we consider Employment Income Deduction, Basic Exemption, Spousal Exemptions, Exemptions for Dependents, and Social Insurance Premium Deductions, with the additional assumption that $20 \%$ of nonlabor income is deductible.

\section{Table A1}

For cash benefits, we consider child allowance. If households with children have annual earnings that are less than certain levels of income, they are entitled to child 
allowance. The eligibility depends on the level of household income as well as the number of children at specific ages. The income threshold varies as family size changes. In FY 1997, families with children aged three years or younger were eligible if their annual income was below 3.25 million yen (US\$ 32,500), with the income threshold increasing with the number of dependents within the household. The 1997 monthly benefits per child depended on the number and composition of the children: 5,000 yen each for the first and second children and 10,000 yen each for the third and subsequent children.

The government also offers another type of child allowance called the child rearing allowance. However, since this targets single mothers only, we do not consider it here. Public assistance (PA) benefits may also be worth considering. PA benefits compensate for the difference between the minimum cost of living and the maximum possible earnings of a household. However, it is impossible to obtain individual PA benefits from the observed income data, as income is not the only variable used to determine eligibility for benefits. The means tests consider multiple characteristics of the applicants. The applicants have to exhaust all of their financial assets and prove that they have no support from their family and relatives. If the authority considers that the applicants are able to work, their chances for receiving benefits become quite slim. Fortunately, the proportion of households receiving PA in our samples is negligible; in 1997, the ratio of the number of households receiving PA to the total number of households was $1.41 \%$. In addition, the heads of $93.3 \%$ of households receiving PA were the elderly ( $\geq 65$ years if male and $\geq 60$ years if female), single mothers, the injured, the sick, and the disabled, all of whom are excluded from our samples. Therefore, the share of households receiving PA in our sample should be less than $.095 \%[=.0141 \times(1-.933)]$, and plausibly, even less. See Hayashi (2010) for a general explanation about Japan's social protection system. 
Table 1. Discretized level of annual hours worked

\begin{tabular}{crrrrrr}
\hline Choices & $\begin{array}{c}\text { Annual } \\
\text { Hours } \\
\text { Worked }\end{array}$ & $\begin{array}{c}\text { Lower Limit } \\
\text { (hours) }\end{array}$ & $\begin{array}{c}\text { Upper Limit } \\
\text { (hours) }\end{array}$ & \multicolumn{2}{c}{ Frequencies in Samples } \\
\hline 1 & 0 & 0 & 0 & 9.65 & 2.14 & 41.98 \\
2 & 492 & 1 & 900 & 3.08 & 1.37 & 16.04 \\
3 & 1,177 & 901 & 1,250 & 24.98 & 26.63 & 21.79 \\
4 & 1,484 & 1,251 & 1,550 & 24.94 & 25.79 & 10.39 \\
5 & 1,741 & 1,551 & 1,750 & 12.95 & 13.62 & 3.85 \\
6 & 1,849 & 1,751 & 2,000 & 6.89 & 8.53 & 2.85 \\
7 & 2,140 & 2,001 & 2,200 & 8.51 & 10.79 & 1.97 \\
8 & 2,679 & 2,201 & 3,000 & 9.00 & 11.13 & 1.13 \\
\hline Total & & & & 100.00 & 100.00 & 100.00 \\
\hline
\end{tabular}


Table 2a. Sample statistics: single-member households

\begin{tabular}{|c|c|c|c|c|c|c|}
\hline & & Mean & S.D. & Min & Median & Max \\
\hline \multirow{6}{*}{ Age (years) } & $1\{25 \leq$ age $\leq 29\}$ & .285 & .452 & 0 & 0 & 1 \\
\hline & $1\{30 \leq$ age $\leq 34\}$ & .139 & .347 & 0 & 0 & 1 \\
\hline & $1\{35 \leq$ age $\leq 39\}$ & .097 & .296 & 0 & 0 & 1 \\
\hline & $1\{40 \leq$ age $\leq 44\}$ & .121 & .326 & 0 & 0 & 1 \\
\hline & $1\{45 \leq$ age $\leq 49\}$ & .183 & .387 & 0 & 0 & 1 \\
\hline & $1\{50 \leq$ age $\leq 54\}$ & .174 & .379 & 0 & 0 & 1 \\
\hline \multirow{2}{*}{ Gender } & $1\{$ male $\}$ & .742 & .438 & 0 & 1 & 1 \\
\hline & $1\{$ female $\}$ & .258 & .438 & 0 & 0 & 1 \\
\hline \multirow{4}{*}{ Education } & $1\{$ junior high school $\}$ & .141 & .348 & 0 & 0 & 1 \\
\hline & $1\{$ senior high school $\}$ & .400 & .490 & 0 & 0 & 1 \\
\hline & 1 \{junior college $\}$ & .118 & .323 & 0 & 0 & 1 \\
\hline & $1\{$ university or higher $\}$ & .342 & .474 & 0 & 0 & 1 \\
\hline \multicolumn{2}{|c|}{ Residence in one of the three major urban areas } & .585 & .493 & 0 & 1 & 1 \\
\hline \multicolumn{2}{|c|}{ Gross wage rate (fitted) $(10,000$ yen/hour) } & .264 & .152 & .003 & .266 & .753 \\
\hline \multicolumn{2}{|c|}{ Total household income (10,000 yen/year) } & 457 & 328 & 25 & 450 & 3,000 \\
\hline
\end{tabular}

The sample size is 19,735 . 
Table 2b. Sample statistics: couples with or without children

\begin{tabular}{|c|c|c|c|c|c|c|}
\hline & & Mean & S.D. & Min & Median & Max \\
\hline \multirow{6}{*}{ Husband: Age (years) } & $1\{25 \leq$ age $\leq 29\}$ & .028 & 0.164 & 0 & 0 & 1 \\
\hline & $1\{30 \leq$ age $\leq 34\}$ & .044 & 0.206 & 0 & 0 & 1 \\
\hline & $1\{35 \leq$ age $\leq 39\}$ & .075 & 0.263 & 0 & 0 & 1 \\
\hline & $1\{40 \leq$ age $\leq 44\}$ & .182 & 0.386 & 0 & 0 & 1 \\
\hline & $1\{45 \leq$ age $\leq 49\}$ & .349 & 0.477 & 0 & 0 & 1 \\
\hline & $1\{50 \leq$ age $\leq 54\}$ & .322 & 0.467 & 0 & 0 & 1 \\
\hline \multirow{4}{*}{ Husband: Education } & $1\{$ junior high school $\}$ & .144 & 0.351 & 0 & 0 & 1 \\
\hline & $1\{$ senior high school $\}$ & .451 & 0.498 & 0 & 0 & 1 \\
\hline & 1 \{junior college $\}$ & .055 & 0.227 & 0 & 0 & 1 \\
\hline & 1 \{university or higher\} & .350 & 0.477 & 0 & 0 & 1 \\
\hline \multirow{6}{*}{ Wife: Age (years) } & $1\{25 \leq$ age $\leq 29\}$ & .053 & 0.224 & 0 & 0 & 1 \\
\hline & $1\{30 \leq$ age $\leq 34\}$ & .029 & 0.168 & 0 & 0 & 1 \\
\hline & $1\{35 \leq$ age $\leq 39\}$ & .089 & 0.285 & 0 & 0 & 1 \\
\hline & $1\{40 \leq$ age $\leq 44\}$ & .295 & 0.456 & 0 & 0 & 1 \\
\hline & $1\{45 \leq$ age $\leq 49\}$ & .377 & 0.485 & 0 & 0 & 1 \\
\hline & $1\{50 \leq$ age $\leq 54\}$ & .152 & 0.359 & 0 & 0 & 1 \\
\hline \multirow{4}{*}{ Wife: Education } & 1 \{junior high school\} & .103 & 0.305 & 0 & 0 & 1 \\
\hline & $1\{$ senior high school $\}$ & .505 & 0.500 & 0 & 1 & 1 \\
\hline & 1 \{junior college $\}$ & .244 & 0.430 & 0 & 0 & 1 \\
\hline & $1\{$ university or higher $\}$ & .148 & 0.355 & 0 & 0 & 1 \\
\hline \multirow{3}{*}{$\begin{array}{l}\text { Number of Children } \\
\text { (Age, years) }\end{array}$} & age $\leq 6$ & .153 & .448 & 0 & 0 & 4 \\
\hline & $7 \leq$ age $\leq 14$ & .474 & .776 & 0 & 0 & 5 \\
\hline & $15 \leq$ age & .777 & .854 & 0 & 1 & 4 \\
\hline \multicolumn{2}{|c|}{ Residence in one of the three major urban areas } & .629 & .483 & 0 & 1 & 1 \\
\hline \multicolumn{2}{|c|}{ Husband: Gross wage rate (fitted) $(10,000$ yen/hour) } & .427 & .123 & .182 & .424 & .753 \\
\hline \multicolumn{2}{|c|}{ Wife: Gross wage rate (fitted) (10,000 yen/hour) } & .060 & .042 & .003 & .049 & .276 \\
\hline \multicolumn{2}{|c|}{ Total household income (10,000 yen/year) } & 951 & 605 & 25 & 850 & 3,000 \\
\hline
\end{tabular}

The sample size is 43,011 . 
Table 3a. Estimation results: singles

\begin{tabular}{|c|c|c|c|c|c|c|c|c|}
\hline \multirow{2}{*}{$\begin{array}{l}\ln \text { (consumption) } \\
\end{array}$} & \multicolumn{2}{|c|}{ Model A1 } & \multicolumn{2}{|c|}{ Model A2 } & \multicolumn{2}{|c|}{ Model A3 } & \multicolumn{2}{|c|}{ Model A4 } \\
\hline & random & nonrandom & random & nonrandom & random & nonrandom & random & nonrandom \\
\hline Coef or E(coef) & $.689^{* * * 1}$ & -.826 & .055 & -1.475 & $-2.419^{* * * *}$ & $-4.106^{* * * *}$ & -.776 & $-2.749^{*}$ \\
\hline Coel. or Le(coel.) & $(.342)$ & $(.275)$ & $(.545)$ & $(.466)$ & $(.704)$ & $(.586)$ & $(.726)$ & $(.627)$ \\
\hline $\operatorname{var}(\operatorname{coef})^{1 / 2}$ & $.364^{* * * *}$ & n.a. & $.268^{* * * *}$ & n.a. & $.204^{* * *}$ & n.a. & $.450^{* * *}$ & n.a. \\
\hline & $(.049)$ & n.a. & $(.038)$ & n.a. & $(.033)$ & n.a. & $(.059)$ & n.a. \\
\hline $\ln$ (leisure) & $\begin{array}{c}47.866^{* * * *} \\
(3.301)\end{array}$ & $\begin{array}{c}56.723 \\
(3.025)\end{array}$ & $\begin{array}{l}55.608^{*} \\
(3.342)\end{array}$ & $\begin{array}{c}62.035 \\
(3.119)\end{array}$ & $\begin{array}{l}53.531 \\
(3.337)\end{array}$ & $\begin{array}{c}57.222^{*} \\
(3.185)\end{array}$ & $\begin{array}{l}47.325 \\
(3.551)\end{array}$ & $\begin{array}{c}50.743 \\
(3.345)\end{array}$ \\
\hline $\ln (\text { consumntion })^{2}$ & $.033^{* * * *}$ & $.044^{* * * * *}$ & $.034^{* * * * *}$ & $.039^{* * * * * 3}$ & $.036^{* * * *}$ & $.038^{* * * * *}$ & $.023^{* * * * *}$ & $.053^{* * * *}$ \\
\hline m(coorsumptionil) & $(.005)_{* * *}$ & $(.002)_{* * *}$ & $(.004)$ & $(.003)$ & $(.003)$ & $(.003)$ & $(.006)$ & $(.003)$ \\
\hline $\ln (\text { leisure })^{2}$ & $-5.871^{* * * *}$ & $-7.261^{* * *}$ & $-6.823^{* * *}$ & $-7.871^{* * *}$ & $-6.769^{* * *}$ & $-7.455^{* * * *}$ & $-5.755^{* * *}$ & $-6.426^{* * * *}$ \\
\hline $\ln$ (leisure) & $.145^{* * *}$ & $-2.551^{{ }^{* * * *}}$ & $.259^{* *}$ & $\begin{array}{l}(.413) \\
.565^{* * *}\end{array}$ & $\begin{array}{l}(.446) \\
.842^{* * * *}\end{array}$ & $1.206^{* * * *}$ & $\begin{array}{l}(.4 / 6) \\
.500^{* * *}\end{array}$ & $.913^{* * *}$ \\
\hline$\times \ln ($ consumption $)$ & $(.082)$ & $(.052)$ & $(.131)$ & $(.115)$ & $(.168)$ & $(.144)$ & $(.173)$ & $(.154)$ \\
\hline Fixed cost & $\begin{array}{l}-2.454^{* * * *} \\
(055)\end{array}$ & $-.826^{* * *}$ & $-2.405^{* * *}$ & $-2.465^{* * *}$ & $-2.419^{* * * *}$ & $-2.456^{* * * *}$ & $-2.326^{* * *}$ & $-2.424^{* * * *}$ \\
\hline $\ln$ (leisure) & & & $-1.648^{* * * * *}$ & $-1.641^{* * * *}$ & $-1.005^{\text {***** }}$ & $-.801^{* * * *}$ & $-1.193^{* * * *}$ & $-1.000^{* * * *}$ \\
\hline$\times 1\{30 \leq$ age $\leq 34\}$ & & & $(.175)$ & $(.163)$ & $(.212)$ & $(.198)$ & $(.252)$ & $(.226)$ \\
\hline $\ln ($ leisure) & & & $-2.273^{* * * *}$ & $-2.238^{* * * *}$ & $-1.758^{* * * *}$ & $-1.575^{\text {**** }}$ & $-1.769^{* * * *}$ & $-1.715^{* * * *}$ \\
\hline$\times 1\{35 \leq$ age $\leq 39\}$ & & & $(.206)$ & $(.195)$ & $(.224)$ & $(.213)$ & $(.273)$ & $(.244)$ \\
\hline $\ln ($ leisure $)$ & & & $-1.663^{* * *}$ & $-1.660^{* * *}$ & $-1.253^{* * *}$ & $-1.118^{* * *}$ & $-1.381^{* * *}$ & $-1.250^{* * * *}$ \\
\hline$\times 1\{40 \leq$ age $\leq 44\}$ & & & $(.224)$ & $(.212)$ & $(.235)$ & $(.224)$ & $(.288)$ & $(.259)$ \\
\hline $\ln$ (leisure) & & & $-1.029^{* * * *}$ & $-1.012^{* * *}$ & $-.790^{* * * *}$ & $-.691^{* * * *}$ & $-1.007^{* * *}$ & $-.895^{* * * *}$ \\
\hline$\times 1\{45 \leq$ age $\leq 49\}$ & & & $(.203)$ & $(.190)$ & $(.206)$ & $(.196)$ & $(.254)$ & $(.227)$ \\
\hline $\ln ($ leisure $)$ & & & $-.478^{* * * *}$ & $-.483^{* * *}$ & $-.391^{* *}$ & $-.358^{* *}$ & $-.376^{*}$ & $-.377^{*}$ \\
\hline$\times 1\{50 \leq$ age $\leq 55\}$ & & & $(.179)$ & $(.166)$ & $(.177)$ & $(.168)$ & $(.221)$ & $(.196)$ \\
\hline $\ln ($ leisure $)$ & & & $.083^{* * *}$ & .339 & $1.033^{* * * *}$ & $1.493^{* * * *}$ & $1.127^{* * * *}$ & $1.529^{* * * *}$ \\
\hline$\times 1\{$ woman $\}$ & & & $(.252)$ & $(.225)$ & $(.308)$ & $(.276)$ & $(.332)$ & $(.289)$ \\
\hline $\ln ($ leisure $)$ & & & $-.202^{*}$ & $-.191^{*}$ & $-.216^{*}$ & $-.213^{* * * *}$ & .026 & -.113 \\
\hline$\times 1\{$ urban area $\}$ & & & $(.113)$ & $(.106)$ & $(.111)$ & $(.106)$ & $(.140)$ & $(.123)$ \\
\hline $\ln ($ leisure $)$ & & & & & $.611^{* * *}$ & $.892^{* * * *}$ & $-.879^{* * * *}$ & -.024 \\
\hline$\times 1\{$ junior high school $\}$ & & & & & $(.194)$ & $(.176)$ & $(.258)$ & $(.200)$ \\
\hline $\ln$ (leisure) & & & & & -.176 & -.228 & .010 & -.053 \\
\hline$\times 1$ junior college $\}$ & & & & & $(.188)$ & $(.178)$ & $(.236)$ & $(.211)$ \\
\hline $\ln ($ leisure $)$ & & & & & $-.682^{* * * *}$ & $-.785^{* * *}$ & -.127 & $-.385^{* * *}$ \\
\hline$\times 1\{$ university $\}$ & & & & & $(.146)$ & $(.139)$ & $(.180)$ & $(.160)$ \\
\hline $\ln ($ consumption $)$ & & & & & & & -.011 & .009 \\
\hline$\times 1\{30 \leq$ age $\leq 34\}$ & & & & & & & $(.035)$ & $(.015)$ \\
\hline $\ln ($ consumption $)$ & & & & & & & .045 & .007 \\
\hline$\times 1\{35 \leq$ age $\leq 39\}$ & & & & & & & $(.042)$ & $(.017)$ \\
\hline $\ln ($ consumption) & & & & & & & .005 & .003 \\
\hline$\times 1\{40 \leq$ age $\leq 44\}$ & & & & & & & $(.043)$ & $(.018)$ \\
\hline $\ln ($ consumption $)$ & & & & & & & -.031 & -.015 \\
\hline$\times 1\{45 \leq$ age $\leq 49\}$ & & & & & & & $(.037)$ & $(.015)$ \\
\hline $\ln ($ consumption $)$ & & & & & & & .015 & .005 \\
\hline$\times 1\{50 \leq$ age $\leq 55\}$ & & & & & & & $(.033)_{* * *}$ & $(.013)$ \\
\hline $\begin{array}{l}\ln (\text { consumption }) \\
\times 1\{\text { woman }\}\end{array}$ & & & & & & & $\begin{array}{l}.123^{* .3} \\
(.029)\end{array}$ & $\begin{array}{l}.141^{(x+k} \\
(.014)\end{array}$ \\
\hline $\ln ($ consumption $)$ & & & & & & & $.063^{* * *}$ & $.016^{*}$ \\
\hline$\times 1\{$ urban area $\}$ & & & & & & & $(.023)$ & $(.009)$ \\
\hline $\ln ($ consumption $)$ & & & & & & & $-.304^{* * * *}$ & $-.068^{* * * *}$ \\
\hline$\times 1\{$ junior high school $\}$ & & & & & & & $(.050)$ & $(.011)$ \\
\hline $\ln ($ consumption $)$ & & & & & & & .048 & .018 \\
\hline$\times 1\{$ junior college $\}$ & & & & & & & $(.037)$ & $(.017)$ \\
\hline $\ln ($ consumption $)$ & & & & & & & $.142^{* * *}$ & $.050^{* * * *}$ \\
\hline$\times 1\{$ university $\}$ & & & & & & & $(.031)$ & $(.013)$ \\
\hline Pseudo- $R^{2}$ & .082 & .084 & .085 & .086 & .086 & .086 & .089 & .089 \\
\hline Log-likelihood & $-37,606$ & $-37,658$ & $-37,513$ & $-37,547$ & $-37,498$ & $-37,517$ & $-37,382$ & $-37,517$ \\
\hline
\end{tabular}

Note: $* * * p \leq .01 ; * * .01<p \leq .05, * .05<p \leq .10$. Standard errors are in parentheses. Sample size is 19,735 . 
Table 3b. Estimation results: couples with or without children

\begin{tabular}{|c|c|c|c|c|c|c|c|c|c|c|}
\hline & \multicolumn{2}{|c|}{ Model B1 } & \multicolumn{2}{|c|}{ Model B2 } & \multicolumn{2}{|c|}{ Model B3 } & \multicolumn{2}{|c|}{ Model B4 } & \multicolumn{2}{|c|}{ Model B5 } \\
\hline & Husband & Wife & Husband & Wife & Husband & Wife & Husband & Wife & Husband & Wife \\
\hline $\ln$ (leisure) & $\begin{array}{l}43.914^{* * *} \\
(2.259)\end{array}$ & $\begin{array}{c}147.760^{* * *} \\
(3.814)\end{array}$ & $\begin{array}{c}53.845^{\text {**** }} \\
(2.479)\end{array}$ & $\begin{array}{c}154.947^{* * *} \\
(3.885)\end{array}$ & $\begin{array}{c}61.941^{* * *} \\
(3.183)\end{array}$ & $\begin{array}{c}157.968^{* * * *} \\
(3.908)\end{array}$ & $\begin{array}{c}60.870^{* * *} \\
(3.196)\end{array}$ & $\begin{array}{c}157.945^{* * *} \\
(3.908)\end{array}$ & $\begin{array}{c}60.928^{* * *} \\
(3.199)\end{array}$ & $\begin{array}{c}156.516^{* * *} \\
(3.907)\end{array}$ \\
\hline $\ln (\text { leisure })^{2}$ & $\begin{array}{c}-7.869^{* * *} \\
(.255)\end{array}$ & $\begin{array}{c}-20.101^{* * *} \\
(.471)\end{array}$ & $\begin{array}{l}-9.200^{* * *} \\
(.271)\end{array}$ & $\begin{array}{l}-21.059^{* * * *} \\
(.474)\end{array}$ & $\begin{array}{c}-9.380^{* * *} \\
(.287)\end{array}$ & $\begin{array}{c}-20.986^{* * * *} \\
(.475)\end{array}$ & $\begin{array}{c}-9.389^{* * *} \\
(.288)\end{array}$ & $\begin{array}{l}-21.020^{* * * *} \\
(.475)\end{array}$ & $\begin{array}{c}-9.360^{* * *} \\
(.289)\end{array}$ & $\begin{array}{c}-20.790^{* * * *} \\
(.474)\end{array}$ \\
\hline $\begin{array}{l}\ln (\text { leisure }) \times \\
\ln (\text { consumption })\end{array}$ & $\begin{array}{l}1.226^{* * *} \\
(.132)\end{array}$ & $\begin{array}{l}-1.212^{* * * *} \\
\quad(.088)\end{array}$ & $\begin{array}{l}.586^{* * * *} \\
(.161)\end{array}$ & $\begin{array}{c}-1.400^{* * * *} \\
(.100)\end{array}$ & $\begin{array}{l}-.653^{*} \\
(.374)\end{array}$ & $\begin{array}{c}-1.821^{\text {**** }} \\
(.121)\end{array}$ & $\begin{array}{l}-.346 \\
(.377)\end{array}$ & $\begin{array}{c}-1.784^{* * *} \\
(.121)\end{array}$ & $\begin{array}{l}-.431 \\
(.377)\end{array}$ & $\begin{array}{l}-1.797^{* * *} \\
(.122)\end{array}$ \\
\hline Fixed cost & $\begin{array}{l}.090^{* *} \\
(.045)\end{array}$ & $\begin{array}{c}-1.089^{* * * *} \\
(.026)\end{array}$ & $\begin{array}{l}.127^{* * * *} \\
(.045)\end{array}$ & $\begin{array}{c}-1.083^{* * *} \\
(.026)\end{array}$ & $\begin{array}{l}.130^{\text {**** }} \\
(.045)\end{array}$ & $\begin{array}{c}-1.083^{* * *} \\
(.026)\end{array}$ & $\begin{array}{l}.121^{* * * *} \\
(.045)\end{array}$ & $\begin{array}{c}-1.083^{* * *} \\
(.026)\end{array}$ & $\begin{array}{l}.145^{* * * *} \\
(.046)\end{array}$ & $\begin{array}{c}-.961^{* * *} \\
(.026)\end{array}$ \\
\hline $\begin{array}{l}\ln (\text { leisure }) \times \\
1\{30 \leq \text { age } \leq 34\}\end{array}$ & & & $\begin{array}{l}-2.422^{* * *} \\
(.266)\end{array}$ & $\begin{array}{c}.307 \\
(.202)\end{array}$ & $\begin{array}{c}-3.350^{* * *} \\
(.372)\end{array}$ & $\begin{array}{l}-.479^{* *} \\
(.224)\end{array}$ & $\begin{array}{l}-3.325^{* * *} \\
(.390)\end{array}$ & $\begin{array}{c}-0.546^{* *} \\
(.226)\end{array}$ & $\begin{array}{c}-3.380^{* * * *} \\
(.390)\end{array}$ & $\begin{array}{l}-.560^{* *} \\
(.223)\end{array}$ \\
\hline $\begin{array}{l}\ln (\text { leisure }) \times \\
1\{35 \leq \text { age } \leq 39\}\end{array}$ & & & $\begin{array}{l}-2.432^{* * *} \\
(.219)\end{array}$ & $\begin{array}{l}-.849^{* * *} \\
(.249)\end{array}$ & $\begin{array}{l}-3.013^{* * *} \\
(.291)\end{array}$ & $\begin{array}{l}-1.453^{* * *} \\
(.291)\end{array}$ & $\begin{array}{l}-3.047^{* * *} \\
(.311)\end{array}$ & $\begin{array}{l}-1.527^{* * *} \\
(.294)\end{array}$ & $\begin{array}{c}-3.079^{* * *} \\
(.311)\end{array}$ & $\begin{array}{c}-1.464^{* * *} \\
(.286)\end{array}$ \\
\hline $\begin{array}{l}\ln (\text { leisure }) \times \\
1\{40 \leq \text { age } \leq 44\}\end{array}$ & & & $\begin{array}{l}-2.391^{* * *} \\
(.181)\end{array}$ & $\begin{array}{c}-.528^{* * *} \\
(.171)\end{array}$ & $\begin{array}{c}-2.810^{* * *} \\
(.227)\end{array}$ & $\begin{array}{c}-1.305^{* * *} \\
(.205)\end{array}$ & $\begin{array}{l}-2.926^{* * *} \\
(.245)\end{array}$ & $\begin{array}{c}-1.270^{* * *} \\
(.207)\end{array}$ & $\begin{array}{l}-2.952^{* * *} \\
(.245)\end{array}$ & $\begin{array}{c}-1.254^{* * * *} \\
(.206)\end{array}$ \\
\hline $\begin{array}{l}\ln (\text { leisure }) \times \\
1\{45 \leq \text { age } \leq 49\}\end{array}$ & & & $\begin{array}{c}-.915^{* * *} \\
(.128)\end{array}$ & $\begin{array}{c}-.309^{* * *} \\
(.119)\end{array}$ & $\begin{array}{c}-1.185^{* * *} \\
(.151)\end{array}$ & $\begin{array}{l}-.620^{* * * *} \\
(.126)\end{array}$ & $\begin{array}{c}-1.250^{* * *} \\
(.166)\end{array}$ & $\begin{array}{c}-0.650^{* * *} \\
(.127)\end{array}$ & $\begin{array}{c}-1.267^{* * * *} \\
(.166)\end{array}$ & $\begin{array}{c}-.648^{* * *} \\
(.128)\end{array}$ \\
\hline $\begin{array}{l}\ln (\text { leisure }) \times \\
1\{50 \leq \text { age } \leq 55\}\end{array}$ & & & $\begin{array}{c}-.337^{* * *} \\
(.095)\end{array}$ & $\begin{array}{l}-.188^{*} \\
(.104)\end{array}$ & $\begin{array}{c}-0.464^{* * *} \\
(.101)\end{array}$ & $\begin{array}{l}-.286^{* * *} \\
(.105)\end{array}$ & $\begin{array}{c}-.549^{* * *} \\
(.114)\end{array}$ & $\begin{array}{c}-0.317^{* * *} \\
(.106)\end{array}$ & $\begin{array}{l}-.556^{* * *} \\
(.114)\end{array}$ & $\begin{array}{l}-.320^{* * *} \\
(.107)\end{array}$ \\
\hline $\begin{array}{l}\ln (\text { leisure }) \times \\
\# \text { children } \leq 6\end{array}$ & & & $\begin{array}{c}-.592^{* * * *} \\
(.101)\end{array}$ & $\begin{array}{l}2.124^{* * *} \\
(.107)\end{array}$ & $\begin{array}{l}-.548^{* * *} \\
(.102)\end{array}$ & $\begin{array}{l}2.106^{* * *} \\
(.107)\end{array}$ & $\begin{array}{l}-.614^{* * *} \\
(.115)\end{array}$ & $\begin{array}{l}2.086^{* * *} \\
(.108)\end{array}$ & $\begin{array}{l}-.570^{* * * *} \\
(.116)\end{array}$ & $\begin{array}{c}-.750^{* * *} \\
(.171)\end{array}$ \\
\hline $\begin{array}{l}\ln (\text { leisure }) \times \\
\text { \#children 7-14 }\end{array}$ & & & $\begin{array}{l}-.243^{* * *} \\
(.058)\end{array}$ & $\begin{array}{l}.641^{* * *} \\
(.055)\end{array}$ & $\begin{array}{l}-.213^{* * *} \\
(.058)\end{array}$ & $\begin{array}{l}.605^{* * * *} \\
(.055)\end{array}$ & $\begin{array}{l}-.151^{* * *} \\
(.066)\end{array}$ & $\begin{array}{l}.612^{* * *} \\
(.055)\end{array}$ & $\begin{array}{l}-.151^{* *} \\
(.066)\end{array}$ & $\begin{array}{l}.616^{* * *} \\
(.055)\end{array}$ \\
\hline $\begin{array}{l}\ln (\text { leisure }) \times \\
\text { \#children } \geq 15\end{array}$ & & & $\begin{array}{l}-.239^{* * *} \\
(.051)\end{array}$ & $\begin{array}{l}-.126^{* * * *} \\
(.047)\end{array}$ & $\begin{array}{c}-0.233^{* * *} \\
(.051)\end{array}$ & $\begin{array}{l}-.105^{* *} \\
(.048)\end{array}$ & $\begin{array}{l}-.182^{* * *} \\
(.059)\end{array}$ & $\begin{array}{l}-.092^{*} \\
(.048)\end{array}$ & $\begin{array}{l}-.181^{* * * *} \\
(.059)\end{array}$ & $\begin{array}{c}-.097^{* *} \\
(.048)\end{array}$ \\
\hline $\begin{array}{l}\ln (\text { leisure }) \times \\
1\{\text { urban area }\}\end{array}$ & & & $\begin{array}{l}.557^{* * *} \\
(.086)\end{array}$ & $\begin{array}{l}-2.415^{* * *} \\
(.078)\end{array}$ & $\begin{array}{l}.325^{* * *} \\
(.098)\end{array}$ & $\begin{array}{l}-2.380^{* * * *} \\
(.080)\end{array}$ & $\begin{array}{l}.431^{* * * *} \\
(.106)\end{array}$ & $\begin{array}{l}-2.389^{* * *} \\
(.080)\end{array}$ & $\begin{array}{l}.418^{* * * *} \\
(.106)\end{array}$ & $\begin{array}{l}-2.388^{* * *} \\
(.080)\end{array}$ \\
\hline $\begin{array}{l}\ln (\text { leisure }) \times \\
1\{\text { junior high school }\}\end{array}$ & & & & & $\begin{array}{l}-.953^{* * *} \\
(.175)\end{array}$ & $\begin{array}{l}-.764^{* * * *} \\
(.129)\end{array}$ & $\begin{array}{c}-1.159^{* * *} \\
(.180)\end{array}$ & $\begin{array}{l}-.785^{* * * *} \\
(.130)\end{array}$ & $\begin{array}{c}-1.187^{* * * *} \\
(.180)\end{array}$ & $\begin{array}{l}-.799^{* * *} \\
(.131)\end{array}$ \\
\hline $\begin{array}{l}\ln (\text { leisure }) \times \\
1\{\text { junior college }\}\end{array}$ & & & & & $\begin{array}{l}.041 \\
(.177)\end{array}$ & $\begin{array}{l}.690^{* * *} \\
(.102)\end{array}$ & $\begin{array}{l}-.023 \\
(.202)\end{array}$ & $\begin{array}{l}.690^{* * *} \\
(.103)\end{array}$ & $\begin{array}{l}-.014 \\
(.202)\end{array}$ & $\begin{array}{l}.695^{* * *} \\
(.103)\end{array}$ \\
\hline $\begin{array}{l}\ln (\text { leisure }) \times \\
1\{\text { university }\}\end{array}$ & & & & & $\begin{array}{l}-.149 \\
(.130)\end{array}$ & $\begin{array}{l}.573^{* * * *} \\
(.163)\end{array}$ & $\begin{array}{l}-.198 \\
(.140)\end{array}$ & $\begin{array}{l}.560^{* * * *} \\
(.166)\end{array}$ & $\begin{array}{l}-.177 \\
(.140)\end{array}$ & $\begin{array}{l}.601^{* * * *} \\
(.166)\end{array}$ \\
\hline $\begin{array}{l}\ln (\text { consumption }) \times \\
1\{30 \leq \text { age } \leq 34\}\end{array}$ & & & & & & & $\begin{array}{l}-.025 \\
(.056)\end{array}$ & $\begin{array}{l}-.112^{* *} \\
(.050)\end{array}$ & $\begin{array}{l}-.021 \\
(.056)\end{array}$ & $\begin{array}{l}-.111^{* * *} \\
(.050)\end{array}$ \\
\hline $\begin{array}{l}\ln (\text { consumption }) \times \\
1\{35 \leq \text { age } \leq 39\}\end{array}$ & & & & & & & $\begin{array}{l}-.029 \\
(.051)\end{array}$ & $\begin{array}{l}-.153^{* * * *} \\
(.055)\end{array}$ & $\begin{array}{l}-.026 \\
(.052)\end{array}$ & $\begin{array}{l}-.153^{* * * *} \\
(.056)\end{array}$ \\
\hline $\begin{array}{l}\ln (\text { consumption }) \times \\
1\{40 \leq \text { age } \leq 44\}\end{array}$ & & & & & & & $\begin{array}{l}-.087^{* *} \\
(.034)\end{array}$ & $\begin{array}{l}-.008 \\
(.042)\end{array}$ & $\begin{array}{c}-.087^{* *} \\
(.034)\end{array}$ & $\begin{array}{l}-.006 \\
(.043)\end{array}$ \\
\hline $\begin{array}{l}\ln (\text { consumption }) \times \\
1\{45 \leq \text { age } \leq 49\}\end{array}$ & & & & & & & $\begin{array}{l}-.037 \\
(.024)\end{array}$ & $\begin{array}{l}-.060^{* *} \\
(.025)\end{array}$ & $\begin{array}{l}-.037 \\
(.024)\end{array}$ & $\begin{array}{l}-.059^{* *} \\
(.025)\end{array}$ \\
\hline $\begin{array}{l}\ln (\text { consumption }) \times \\
1\{50 \leq \text { age } \leq 55\}\end{array}$ & & & & & & & $\begin{array}{l}-.026 \\
(.019)\end{array}$ & $\begin{array}{l}-.045^{* *} \\
(.020)\end{array}$ & $\begin{array}{l}-.026 \\
(.019)\end{array}$ & $\begin{array}{l}-.045^{* * *} \\
(.020)\end{array}$ \\
\hline $\begin{array}{l}\ln (\text { consumption }) \times \\
1\{\text { junior high school }\}\end{array}$ & & & & & & & $\begin{array}{c}-.073^{* * *} \\
(.018)\end{array}$ & $\begin{array}{c}-.071^{* * *} \\
(.018)\end{array}$ & $\begin{array}{c}-.072^{* * *} \\
(.018)\end{array}$ & $\begin{array}{c}-.070^{* * *} \\
(.018)\end{array}$ \\
\hline $\begin{array}{l}\ln (\text { consumption }) \times \\
1\{\text { junior college }\}\end{array}$ & & & & & & & $\begin{array}{l}-.020 \\
(.031)\end{array}$ & $\begin{array}{c}.027 \\
(.021)\end{array}$ & $\begin{array}{l}-.019 \\
(.031)\end{array}$ & $\begin{array}{l}.027 \\
(.020)\end{array}$ \\
\hline $\begin{array}{l}\ln (\text { consumption }) \times \\
1\{\text { university }\}\end{array}$ & & & & & & & $\begin{array}{l}-.018 \\
(.020)\end{array}$ & $\begin{array}{l}.094^{* * *} \\
(.035)\end{array}$ & $\begin{array}{l}-.018 \\
(.020)\end{array}$ & $\begin{array}{l}.096^{* * *} \\
(.035)\end{array}$ \\
\hline $\begin{array}{l}\text { Fixed cost } \times \\
\# \text { children } \leq 6\end{array}$ & & & & & & & & & $\begin{array}{l}-.375^{* * *} \\
(.128)\end{array}$ & $\begin{array}{l}-.904^{* * *} \\
(.046)\end{array}$ \\
\hline
\end{tabular}

Note: $* * * p \leq .01 ; * * .01<p \leq .05, * .05<p \leq .10$. Standard errors are in parentheses. Sample size is $2,745,110$. 
Table 3b (continued). Estimation results: couples with or without children

\begin{tabular}{|c|c|c|c|c|c|c|c|c|c|c|}
\hline & \multicolumn{2}{|c|}{ Model B1 } & \multicolumn{2}{|c|}{ Model B2 } & \multicolumn{2}{|c|}{ Model B3 } & \multicolumn{2}{|c|}{ Model B4 } & \multicolumn{2}{|c|}{ Model B5 } \\
\hline & Coefficient & S.E. & Coefficient & S.E. & Coefficient & S.E. & Coefficient & S.E. & Coefficient & S.E. \\
\hline $\ln ($ consumption) & .766 & $(.672)$ & $4.061^{* * *}$ & $(.793)$ & $10.970^{* * *}$ & $(1.831)$ & $9.567^{* * *}$ & $(1.844)$ & $9.980^{* * *}$ & (1.845) \\
\hline $\ln (\text { consumption })^{2}$ & $.057^{* * *}$ & $(.003)$ & $.051^{* * *}$ & $(.003)$ & $.062^{* * *}$ & $(.004)$ & $.056^{* * * *}$ & $(.004)$ & $.058^{* * * *}$ & $(.004)$ \\
\hline $\begin{array}{l}\ln (\text { leisure-husband }) \times \\
\ln (\text { leisure-wife })\end{array}$ & $3.599^{* * *}$ & $(.301)$ & $4.132^{* * *}$ & $(.324)$ & $3.456^{* * *}$ & $(.341)$ & $3.506^{* * *}$ & $(.341)$ & $3.509^{* * *}$ & $(.341)$ \\
\hline $\begin{array}{l}\ln (\text { consumption }) \times \\
\text { \#children } \leq 6\end{array}$ & & & & & & & $-.032^{*}$ & $(.018)$ & .009 & $(.022)$ \\
\hline $\begin{array}{l}\ln (\text { consumption }) \times \\
\text { \#children } 7-14\end{array}$ & & & & & & & $.017^{*}$ & $(.010)$ & $.017^{*}$ & (.010) \\
\hline $\begin{array}{l}\ln (\text { consumption }) \times \\
\text { \#children } \geq 15\end{array}$ & & & & & & & $.023^{* *}$ & $(.000)$ & $.022^{* *}$ & $(.000)$ \\
\hline $\begin{array}{l}\ln (\text { consumption }) \times \\
1\{\text { urban area }\}\end{array}$ & & & & & & & .016 & $(.014)$ & .017 & $(.014)$ \\
\hline $\begin{array}{l}\text { S.D. of the coefficient } \\
\text { on consumption }\end{array}$ & .001 & $(.036)$ & .001 & $(.032)$ & .001 & $(.033)$ & .004 & $(.064)$ & .004 & $(.063)$ \\
\hline Pseudo- $R^{2}$ & \multicolumn{2}{|c|}{.145} & \multicolumn{2}{|c|}{.152} & \multicolumn{2}{|c|}{.152} & \multicolumn{2}{|c|}{.152} & \multicolumn{2}{|c|}{.154} \\
\hline Log-likelihood & \multicolumn{2}{|c|}{$-152,873$} & \multicolumn{2}{|c|}{$-151,736$} & \multicolumn{2}{|c|}{$-151,672$} & \multicolumn{2}{|c|}{$-151,630$} & \multicolumn{2}{|c|}{$-151,399$} \\
\hline
\end{tabular}

Note: $* * * p \leq .01 ; * * .01<p \leq .05, * .05<p \leq .10$. Standard errors are in parentheses. Sample size is 42,978 . 
Table 4. Gross wage elasticities of labor supply

\begin{tabular}{|c|c|c|c|c|c|c|}
\hline \multicolumn{2}{|c|}{ Responses of: } & For $1 \%$ Change in: & Mean & S.D. & Min & Max \\
\hline \multicolumn{2}{|l|}{ Singles } & Own wage rate & $\begin{array}{l}.016 \\
(.024)\end{array}$ & $\begin{array}{l}.019 \\
(.091)\end{array}$ & $\begin{array}{c}-.028 \\
(-.532)\end{array}$ & $\begin{array}{c}.076 \\
(.594)\end{array}$ \\
\hline \multirow{4}{*}{ Couples } & \multirow{2}{*}{ Husband } & Own wage rate & $\begin{array}{c}.042 \\
(.053)\end{array}$ & $\begin{array}{c}.009 \\
(.024)\end{array}$ & $\begin{array}{c}.025 \\
(-.086)\end{array}$ & $\begin{array}{c}.069 \\
(.148)\end{array}$ \\
\hline & & Wife's wage rate & $\begin{array}{c}-.008 \\
(-.006)\end{array}$ & $\begin{array}{c}.007 \\
(.008)\end{array}$ & $\begin{array}{c}-.025 \\
(-.052)\end{array}$ & $\begin{array}{c}.009 \\
(.038)\end{array}$ \\
\hline & \multirow{2}{*}{ Wife } & Own wage rate & $\begin{array}{c}.063 \\
(.057)\end{array}$ & $\begin{array}{l}.026 \\
(.115)\end{array}$ & $\begin{array}{c}.016 \\
(-.790)\end{array}$ & $\begin{array}{c}.119 \\
(.475)\end{array}$ \\
\hline & & Husband's wage rate & $\begin{array}{l}.130 \\
(.136)\end{array}$ & $\begin{array}{c}.024 \\
(.060)\end{array}$ & $\begin{array}{c}.074 \\
(-.351)\end{array}$ & $\begin{array}{c}.192 \\
(.449)\end{array}$ \\
\hline
\end{tabular}

Note: The quantities in parentheses are the elasticities calculated analytically with the parametric I-EV distribution. 
Table 5. Average simulated SMCFs

\begin{tabular}{|c|c|c|c|c|c|c|}
\hline$\beta_{i}$ & $\rho$ & $\begin{array}{c}\text { Bracket } 1 \\
10 \% \rightarrow 11 \%\end{array}$ & $\begin{array}{c}\text { Bracket } 2 \\
20 \% \rightarrow 21 \%\end{array}$ & $\begin{array}{c}\text { Bracket } 3 \\
30 \% \rightarrow 31 \%\end{array}$ & $\begin{array}{c}\text { Bracket } 4 \\
40 \% \rightarrow 41 \%\end{array}$ & $\begin{array}{c}\text { Bracket } 5 \\
50 \% \rightarrow 51 \%\end{array}$ \\
\hline \multirow{6}{*}{$\left(n_{i}^{1 / 2} \cdot M_{i}\right)^{-\rho}$} & \multirow{2}{*}{.4} & 4.134 & 1.904 & .440 & .260 & .096 \\
\hline & & 5.944 & 2.734 & .772 & .458 & .199 \\
\hline & \multirow{2}{*}{.8} & .284 & .116 & .024 & .013 & .005 \\
\hline & & .411 & .169 & .043 & .024 & .010 \\
\hline & \multirow{2}{*}{1.2} & .0198 & .0071 & .0013 & .0007 & .0003 \\
\hline & & .0287 & .0106 & .0024 & .0013 & .0005 \\
\hline \multirow{6}{*}{$n_{i}^{(1+\rho) / 2} \cdot M_{i}^{-\rho}$} & \multirow{2}{*}{.4} & 5.834 & 2.671 & .750 & .442 & .197 \\
\hline & & 9.233 & 4.240 & 1.394 & .832 & .411 \\
\hline & \multirow{2}{*}{.8} & .403 & .165 & .042 & .023 & .010 \\
\hline & & .642 & .267 & .079 & .044 & .021 \\
\hline & \multirow{2}{*}{1.2} & .028 & .010 & .002 & .0012 & .0005 \\
\hline & & .045 & .017 & .004 & .0024 & .0011 \\
\hline \multirow{6}{*}{$\left(c_{i}^{*}\right)^{-\rho} \frac{\partial c_{i}^{*}}{\partial c_{i}}$} & \multirow{2}{*}{.4} & 2.999 & 1.040 & .312 & .163 & .057 \\
\hline & & 3.052 & 1.063 & 0.319 & 0.168 & 0.057 \\
\hline & \multirow{2}{*}{.8} & .422 & .137 & .027 & .014 & .005 \\
\hline & & .430 & .140 & .027 & .015 & .005 \\
\hline & \multirow{2}{*}{1.2} & .080 & .025 & .003 & .002 & .0004 \\
\hline & & .081 & .025 & .003 & .002 & .0004 \\
\hline \multirow{2}{*}{$n_{i}$} & \multirow{2}{*}{-} & 1.316 & .663 & .241 & .151 & .079 \\
\hline & & 1.342 & .680 & .248 & .157 & .080 \\
\hline \multirow{2}{*}{$n_{i}^{1 / 2}$} & \multirow{2}{*}{-} & .854 & .436 & .135 & .085 & .038 \\
\hline & & .870 & .446 & .139 & .088 & .039 \\
\hline
\end{tabular}

Note: We calculate the SMCFs in the shaded cells using a hypothetical sample, where we multiply each of the responsive households by 13 so that the aggregate elasticity of the labor supply of married couples roughly equals .4. 
Table A1. Outline of Japan's income tax system, 1997

\begin{tabular}{|c|c|c|}
\hline & Income Tax & Inhabitants Tax \\
\hline Basic Deduction & 380 & 330 \\
\hline Exemption for Spouses & 380 & 330 \\
\hline Special Exemption for Spouses & 380 & 330 \\
\hline Exemption for Dependents & 380 & 330 \\
\hline Exemption for Specific Dependents & 530 & 410 \\
\hline \multirow[t]{5}{*}{ Employment Income Deduction } & Not over $1,800,40 \%$ & Not over $1,800,40 \%$ \\
\hline & Not over $3,600,30 \%$ & Not over $3,600,30 \%$ \\
\hline & Not over $6,600,20 \%$ & Not over $6,600,20 \%$ \\
\hline & Not over $10,000,10 \%$ & Not over $10,000,10 \%$ \\
\hline & Over $10,000,5 \%$ & Over $10,000,5 \%$ \\
\hline Lower Limit & 650 & 650 \\
\hline \multirow[t]{5}{*}{ Tax Rates } & Not over $3,300,10 \%$ & Not over $2,000,5 \%$ \\
\hline & Over $3,300,20 \%$ & Over $2,000,10 \%$ \\
\hline & Over $9,000,30 \%$ & Over $7,000,15 \%$ \\
\hline & Over $18,000,40 \%$ & \\
\hline & Over $30,000,50 \%$ & \\
\hline
\end{tabular}


Figure 1. Distribution of simulated SMCFs for different income brackets

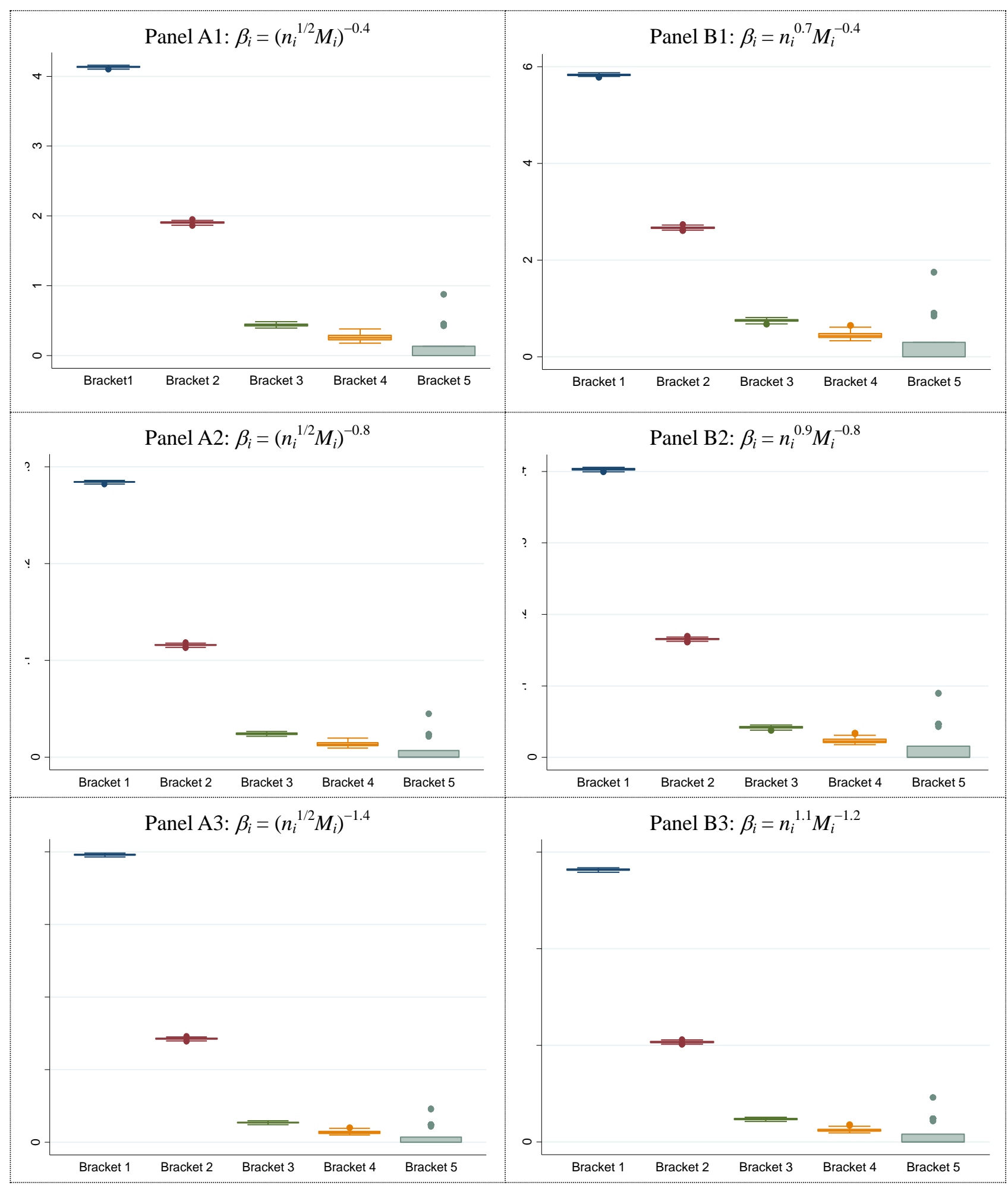


Figure 1 (continued). Distribution of simulated SMCFs for different income brackets

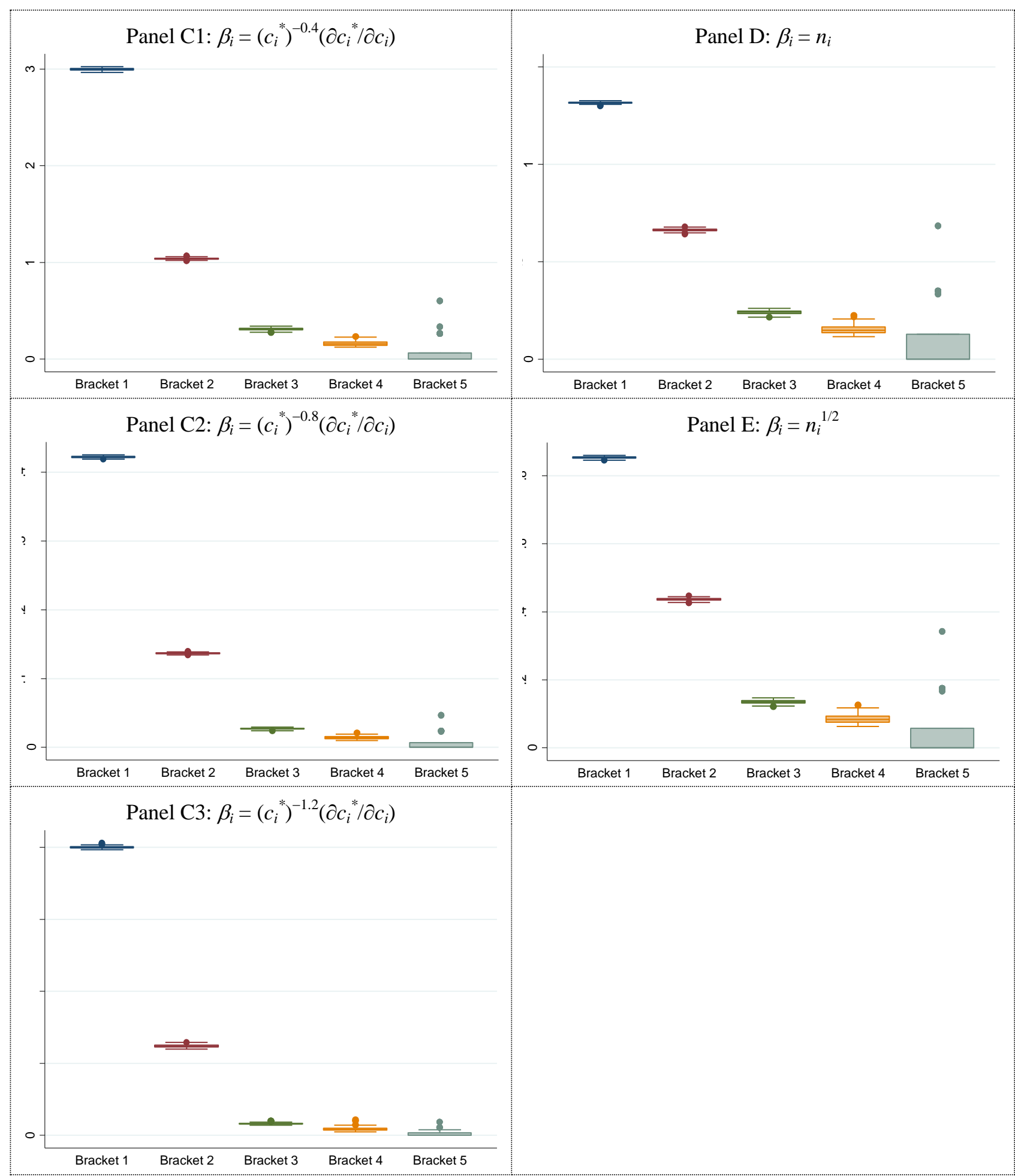


Figure 2. Histograms of SMCFs in Panels C1-C3

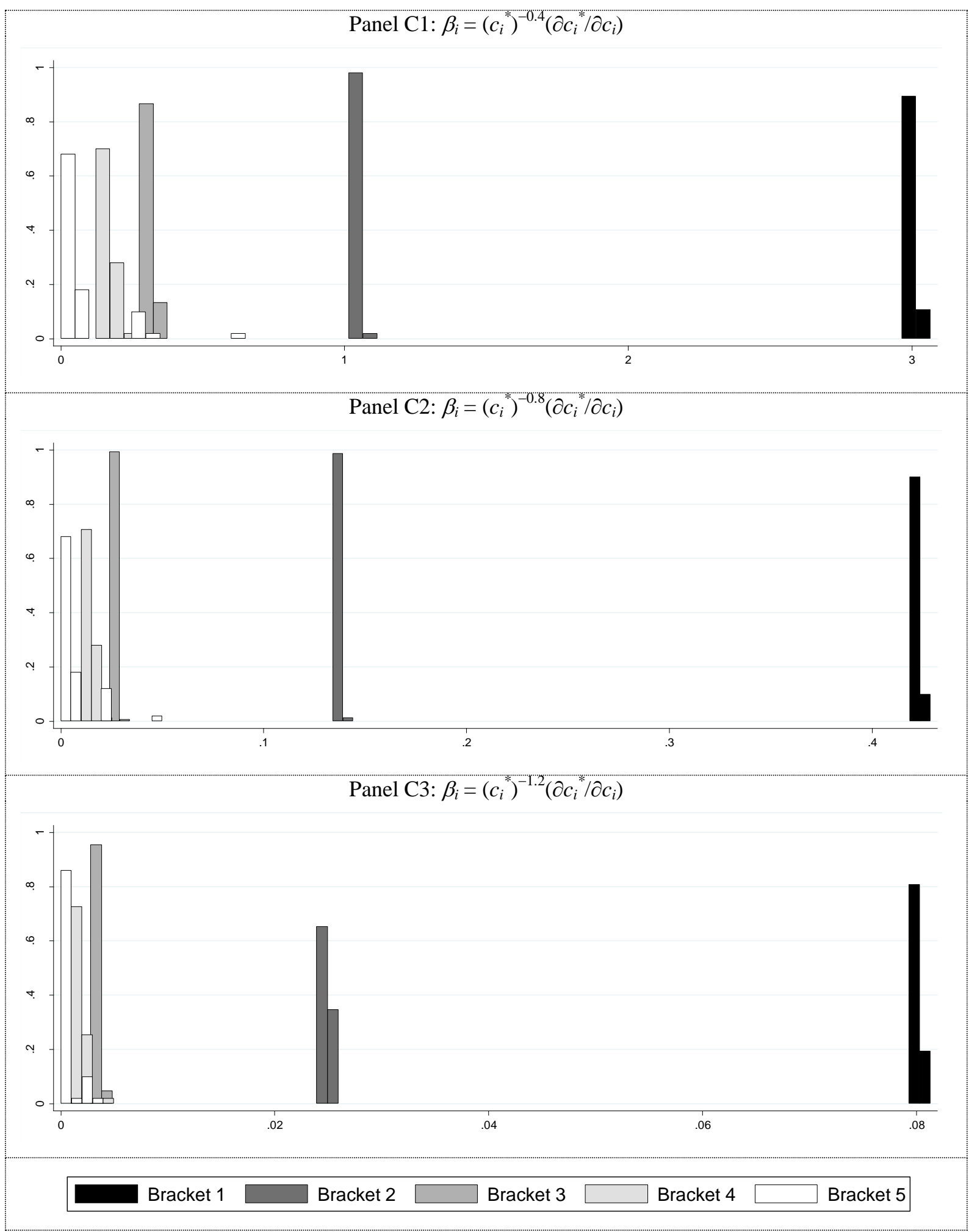

